\title{
Mission Statement Content and Firm Diversification: A ContingenCy Approach
}

\author{
Rebecca J. Morris \\ University of Nebraska at Omaha \\ Omaha, NE
}

\section{Introduction}

The starting point for most models of strategic management has been the creation of a mission statement (David, 1993; Digman, 1990; Hill \& Jones, 1992; Thompson \& Strickland, 1992; etc.). The mission statement serves to set the organizational context within which strategic decisions will be made (Hill \& Jones, 1992). As "an enduring statement of purpose that distinguishes one business from other similar firms" (Pearce, 1982: 15), the mission statement is the "ultimate guiding force that governs where the firm's critical resources will be deployed" (Boseman \& Phatak, 1989: 7).

In its simplest form, the mission statement describes the nature and concept of the firm's future business. It establishes what the firm plans to do and for whom (Below, Morrisey \& Acomb, 1987). The mission statement answers the question "What is our Business?" (Drucker, 1973). In defining the business of the firm, its basic goals, characteristics and guiding philosophies, the mission statement provides the firm with strategic focus and direction (Hill \& Jones, 1992).

Several models have been developed to suggest what elements should be contained in effective mission statements, but these models have typically failed to distinguish between elements necessary for single-business firms versus those for multi-business or diversified firms. Should such a distinction exist? Is the nature of the multi-business firm sufficiently distinct from that of a single business firm to warrant differences in the form of the mission statements?

This paper addresses these questions through a review of the mission statement literature and an exploratory study of the missions of a random sample of Fortune 500 firms. By contrasting the mission statements of single-product, dominant-product and diversified firms, this study was designed to provide guidelines for developing effective mission statements in a variety of strategic contexts.

\section{Mission Statement Components}

\section{Review of Literature}

Although as Steiner (1979) observed, the components and attributes of mission statements are among the least empirically understood issues in strategic management, previous theoretical and conceptual models of mission statements have been used to develop lists of desired components. For example, Abell (1980) suggested that the question "What is out business?" could be answered in terms of three dimensions: (1) what customer groups are being satisfied; (2) what customer need is being satisfied; and (3) how are customer needs being satisfied. 
Want (1986) considered the primary components of the mission statement to be (1) purpose, (2) principle business aims, (3) corporate identity, (4) policies of the company, and (4) corporate values. Kotler (1984) suggested that mission statements should be stated in terms of five key factors: (1) the firm's history, (2) current preferences of management and owners, (3) environmental considerations, (4) available resources, and (5) distinctive competencies.

The scant empirical research regarding mission statements has utilized a list of eight key components of mission statements originally developed by Pearce (1981). These components include:

1. The specification of target customers and markets.

2. The identification of principal/products and services.

3. The specification of geographic domain.

4. The identification of core technologies.

5. The expression of commitment to survival, growth, and profitability.

6. The specification of key elements in the company philosophy.

7. The identification of the company self-concept.

8. The identification of the firm's desired public image.

A ninth element, concern for employees, was later added to this list by David (1989). These nine elements appear to summarize many of the key concerns presented in alternative models of mission statement elements.

Empirical studies using these eight to nine elements have been conducted to examine the relationship of mission statement comprehensiveness (contains all elements) to firm performance (Pearce \& David, 1987), to contrast missions of consumer product firms with those of industrial product firms (David \& Cochran, 1987) and to study the communication effectiveness of mission statements (Cochran \& David, 1986). The assumption in these studies is that the "best" or most effective mission statement is one that contains all of the nine key elements (David, 1993, pg. 102). The results of the Pearce and David (1987) study partially support this assumption. In their study of Fortune 500 firms, they found that six of eight elements were more often associated with high performing firms (philosophy, self-concept, public image, geographic domain, technology and concern for survival).

\section{Different Strategic Contexts}

While agreeing that mission statements may vary in length, content, format and specificity, most models of mission statement components do not discuss differences in mission statements for organizations in different strategic contexts. Should the mission statement of a single-product firm contain the same elements as the mission for a highly diversified firm? Campbell (1989: 7) asks the question "How diversified can a group of companies (businesses) be before it becomes impossible to have a shared sense of mission?" He further indicates that based on his consultations with many companies that it is possible to create a single mission statement for a multi-business company only so long as the level of diversity remains low. Mission statements may not be appropriate when the company is a diversified conglomerate or holding company according to Klemm, Sanderson and Luffman (1991). ${ }^{1}$ 
In strategy formulation, differences in organizational context are thought to be significant enough to require the creation of a strategy hierarchy with separate levels of strategy to deal with corporate concerns versus those of the business level. Some mission statement models have made this distinction as well.

Hill and Jones (1992) provide a separate list of mission statement components for diversified companies. Because the business of a diversified company is the management of a collection of businesses, the question "What is our business?" must be answered with a portfolio orientation. A portfolio approach to business definition in the mission statement should include: (1) the purpose of the company's portfolio of businesses, (2) the desired scope (diversity) of the portfolio, and (3) the balance desired between different businesses in the portfolio (Hill \& Jones, 1992). The firm's corporate mission is then supplemented with the mission statements of each business unit. Business unit missions follow the formats outlined in the previous section.

Wright, Pringle and Kroll (1992) distinguish between the mission at the corporate level and at the business unit level without providing much guidance as to what the mission should contain at each level. Missions at the corporate level should be stated in fairly broad terms while still providing a sense of direction for the company. At the business level, the mission becomes more clearly defined and narrower in scope. Similarly, David (1993) advocates a hierarchy of missions for the multidivisional organization with an overall corporate mission statement and a separate statement for each of its divisions.

Despite Pearce and David's (1987) identification of this area as a "more intriguing question" for future research, previous empirical investigations have not considered the level of diversification in analysis of mission statements and their relationship to firm financial performance. If the differences in effective mission statements of diversified firms are as pronounced as suggested in the theoretical literature, failure to control for these differences in the research design may confound empirical research.

The need for research in this area is apparent when considering the importance of an effective mission statement to the successful pursuit of a diversification strategy. Ireland and Hitt (1992) suggest that the lack of an effective mission statement may be a contributing factor in the high rate of divestitures occurring in large diversified firms especially when diversification is beyond the firm's original scope of operations. Michael Porter's (1987) study of the diversification record of 33 large U.S. firms, supports the notion that diversifications are more successful when firms have a clear concept of the strategic focus of their corporate strategy. Because mission statements serve as a defining framework for evaluating both current and prospective activities (McGinnis, 1981) and provide strategic focus, an effective corporate mission statement serves a critical role in guiding the firm's choices of business units in pursuing diversification.

As Ramanujam and Varadarajan (1989) point out in their comprehensive review of research on corporate diversification, the investigation of the relationship of firm diversification to performance and internal organizational processes has long been a mainstay of strategic management research. Palia, Hitt, Ireland and Godiwalla (1982) 
identify diversification as one of six key contingency variables which explains differences in the way top managers prioritize strategic organizational functions. Their findings indicate that managers of firms of differing levels of diversification consider different organizational functions to be strategically significant in the implementation of their grand corporate strategies. If there are differences in managers' perceptions of the strategic significance of functions such as marketing, production, finance, and public and government relations to the attainment of their chosen strategies, it follows that the mission statements should reflect these differences in prioritization.

It is in this environment that an exploratory study was conducted to.compare the mission statements of firms at differing levels of corporate diversity. It was hypothesized that the mission statements of firms at differing levels of diversification would contain a different mix of the nine key elements of mission statements derived from the literature. Although the mission statement literature has provided little guidance as to how the mix of elements in mission statements might differ, the work of Palia et al. (1982) suggests that differences might be expected in the emphasis on technology and public image components. In their study, managers of diversified firms placed different levels of importance on research and development and engineering functions which are encompassed in the technology mission element. The managers of more diversified firms considered technology factors to be of greater strategic importance than managers of less diversified firms, thus suggesting that diversified firms would be more likely to include a technology component in their mission statements than less diversified firms. Managers of diversified firms also considered public and government relations to be more strategically important to their firm's success than managers of less diversified firms. This suggests that diversified firms may be more likely to address public image issues in their mission statements than less diversified firms. In the Palia et al. study (1982), no statistical difference was observed by level of corporate diversity in the managers perceptions of the strategic importance of organizational functions that correspond to mission elements such as products, customers, geographic domain, employees and corporate philosophy.

The previously cited relationship of effective mission statements to the success of diversification strategies suggested a need to investigate the connection between firm financial performance and mission statement content. The current study was designed to examine the relationship between mission statement content and firm financial performance at different levels of firm diversification as part of the effort to provide empirical support for the linkage between strategic planning and corporate performance.

In keeping with Pearce and David's (1987) call for further research to determine the characteristic strategic contexts when specific mission components are most desirable, the present study addresses the following research questions:

1) Does the mix of mission statement components differ in the mission statements of firms at differing levels of diversification?

2) How do the mission statements of diversified firms differ from less diversified firms? For example, are certain mission statement elements (such as technology and public image) more frequently found in the missions of more diversified firms than those of less diversified firms? 
3) For firms pursuing different levels of corporate diversity, are there differences in the mix of mission statement components associated with superior corporate financial performance?

\section{Annual Reports}

\section{Methodology}

As noted in previous empirical studies of mission statements, many companies do not have formal mission statements. Cochran and David (1986) found that $40.4 \%$ of the 218 Fortune 500 firms responding to their request had no mission statement. Lack of a formal mission statement document should not be interpreted as the firm's failure to consider its mission, purpose or reason for existence. Individuals within the firm may have a clear idea of its mission without creating a formal mission document. A sense of a corporation's mission may be contained in the annual report (David, 1993; Smith, Arnold \& Bizell, 1991). In particular, the letter to shareholders section serves as a good indicator of the major topics attended to by organizational managers (Watzlawick, Beavin \& Jackson, 1967; Bradley \& Baird, 1977) and may provide insight into the firm's values and beliefs (D'Aveni \& MacMillan, 1990). If the firm included its mission statement in the letter to the shareholders as did 52 of the 141 firms (37\%), the mission statement was included in the analysis for this study.

\section{Sample}

A random sample of letters to shareholders for Fortune 500 firms was extracted from the Compustat Corporate Text CD-Rom database for 1990. Only those firms which are publicly held are included in the Compustat database. The final sample included 144 firms representing a wide variety of industries. The sample firms represented approximately half of the Fortune 500 firms available on the CD-Rom for 1990. Missing data further reduced the sample to 141 firms. The sample included firms with 37 two-digit SIC classifications and 55 three-digit SIC classifications, thus representing 37 of the 100 major SIC industry classifications. Average sales for the sample firms were $\$ 9.4$ billion in 1988 with a standard deviation of $\$ 15.3$ million, $\$ 10.0$ billion (Std. Dev. $=\$ 18.6$ million) in 1989 , and $\$ 9.0$ billion (Std. Dev. $=\$ 16.3$ million) in 1990. Firm size ranged from 771 employees to 1,211,900 employees. The average number of employees was 57,312 (Std. Dev.= 137,203). Average return on equity for the sample firms was $12.61 \%$ in 1988 (Std. Dev.=.2548), 4.8\% in 1989 (Std. Dev.=.6670), and 6.27\% in 1990 (Std. Dev.=.6751).

The letters to the shareholders were supplemented with financial and SIC information extracted from the Disclosure CD-Rom for the same time period.

Because the sample included a mixture of mission statements and letters to shareholders, analysis of variance (ANOVA) was used to determine if there was any difference in the inclusion of the mission elements that could be attributed to differences in the type of document analyzed. No significant difference was detected in the inclusion of the mission elements due to the type of document analyzed. Therefore, the remainder of the analysis does not make any distinction with regard to the original source of the mission information. 


\section{Measurement of Variables}

Level of Diversification. The extent of corporate diversity is defined according to guidelines proposed by Rumelt (1974) as follows:

1. A single-product firm is defined as a firm whose primary commitment is to a single business (Wrigley, 1970). More specifically, this is a firm that derives $95 \%$ or more of its revenues from a single product-market activity.

2. A dominant product firm has a primary commitment to a single business but has diversified to a small degree. Firms are classified as dominant product firms if the revenues due to a single product-market activity are between $70 \%-94 \%$ of total revenues.

3. In diversified firms, less than $70 \%$ of the revenues are derived from any one product-market activity. Diversified firms are further classified as related or unrelated.

a. A related diversified firm has diversified into new areas related to the primary end-product by market or technology.

b. An unrelated diversified firm has diversified into new areas without regard to market or technology relationships to the primary product.

The operationalization of these definitions is depicted in Figure

The first two steps of the classification of the level of diversification of each firm as depicted in Figure 1 were accomplished by using SIC codes as reported in the Disclosure database. According to the manual accompanying Disclosure, additional SIC codes are not assigned to a firm unless the additional product/market activity accounts for a minimum of $10 \%$ of total revenues. The $10 \%$ figure is based on the requirements for industry segment reporting outlined in FASB-14. ${ }^{2}$ Therefore, a firm that is assigned only one SIC code has a specialization ratio of $90 \%$, thus indicating that $90 \%$ or more of its revenues coming from that line of business. A firm with two SIC codes derives at least $10 \%$ of its revenues from its secondary line of business and less than $90 \%$ from its primary line. Firms with three or more SIC codes derive less than $70 \%$ of their revenues from the primary line of business and are classified as diversified firms.

Use of the SIC code in classifying single and dominant product firms resulted in a broadening of the single-product category to encompass all firms with revenues of $90 \%$ or more from a single product/market activity. Normally, firms deriving between $5 \%$ and $10 \%$ of their revenues from a secondary product/market activity should be classified as dominant product firms (Rumelt, 1974). However, the SIC classification method does not permit this distinction and classifies these firms instead as single-product firms. It was thought that this problem would affect very few firms and would not distort the subsequent analysis. Use of SIC codes in classifying firm diversification closely approximates the method used by Rumelt (1974) which was later validated in Chatterjee and Blocher (1992). ${ }^{3}$ 
Figure 1

Classification Process for Level of Diversification Using SIC Codes and Nature of Diversification

Single-Product

Business

$\mathrm{SR}>=0.90^{*}$

Dominant Product

Business

$\mathrm{SR}>=0.70$

Unrelated Product

Diversification

Business

$\mathrm{SR}<0.70, \mathrm{RR}<0.70$

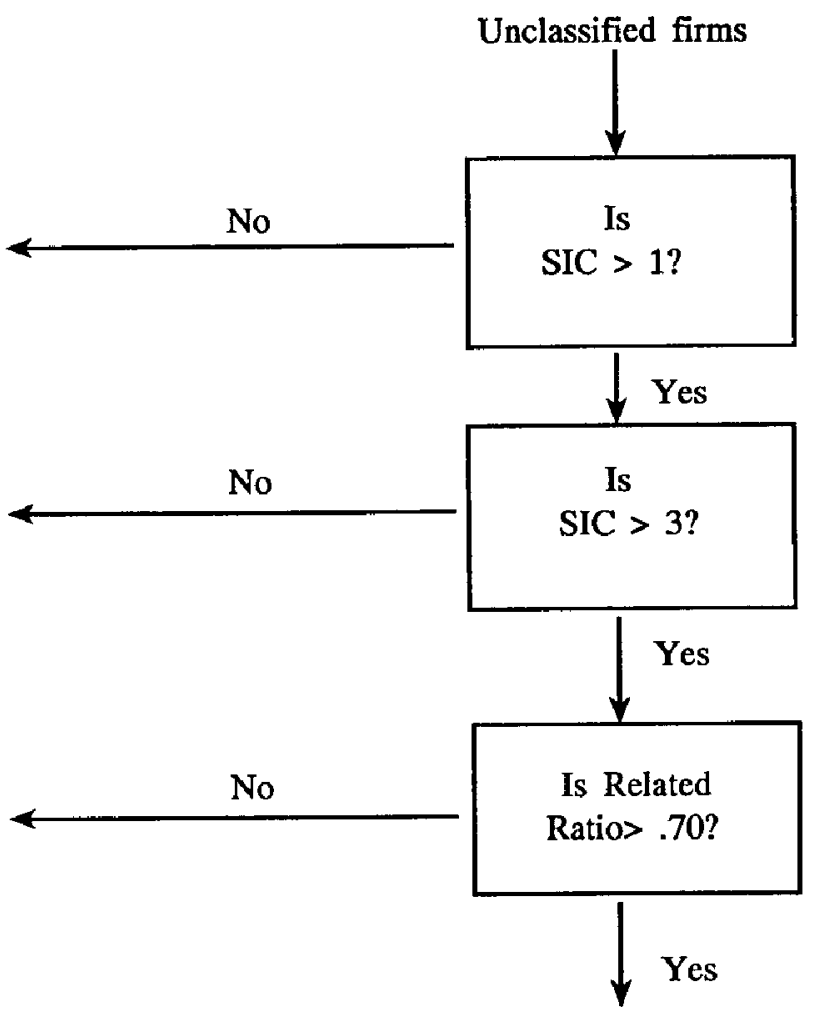

Related Diversification

Business

$\mathrm{SR}<0.70, \mathrm{RR}>.70$

*SR represents Specialization Ratio or the firm's revenue attributable to its largest product-market activity (Rumelt, 1974)

RR represents Related Ratio or the proportion of each firm's revenue coming from its largest group of related businesses.

Based on Palia, Hitt, Ireland and Godiwalla (1982)

Classification of the nature of diversification (either related or unrelated) was accomplished using the method outlined in Rumelt (1974) and Montgomery (1982). The related ratio, or the proportion of each firm's revenue coming from its largest group of related businesses was calculated using the line-of-business data reported in 10-K filings (Chatterjee \& Blocher, 1992). As shown in Figure 1, firms with related ratios of $70 \%$ or greater were considered related diversification firms (Rumelt, 1974). Firms with related ratios of less than $70 \%$ were classified as unrelated diversifications. 
Although there has been some criticism of the use of categorical measures of diversification such as the Rumelt approach rather than continuous measures (see Chatterjee \& Blocher, 1992), the Rumelt approach has been shown to be more effective in investigations of the relationships between diversification and firm-specific managerial variables (Montgomery; 1982). As this study attempts to detect differences in the rate of inclusion of various mission statement components for firms at different levels of diversification, the Rumelt approach appears better suited to the research design than continuous measures.

No statistical difference was observed in the size of the firms classified in each of the four diversification levels. Analysis of variance of firm size as measured by sales for 1988, 1989, 1990 or the number of employees indicated that any differences observed in the later analysis was not due to differences in the firm size but due to the level of diversification.

Mission elements. Computerized content analysis was used to evaluate each of the annual reports to determine whether the nine mission elements were included. Content analysis is a qualitative research technique that uses a set of procedures to classify or categorize communications to permit valid inferences to be drawn (Weber, 1990). The approach used in this study applies computer technology to replicate the research approaches used by Cochran and David (1986), Pearce and David (1987) and David (1989). The advantage of computerization of the content analysis process is that given a valid set of classification rules, the computer will classify the text quickly and reliably thus permitting an examination of larger volumes of qualitative data at lower cost (Gephart \& Wolfe, 1989; Weber, 1990).

For each of the nine mission elements, a list of key words and phrases were developed from a review of the mission statement literature and many actual corporate mission statements (excluding those used in this study). The key words were then entered as search commands in the text management software chosen to perform the content analysis. The ability of the key words to represent the mission element was tested by requesting the computer to apply them to a sample of mission statements (again not those used in this study). The computer recorded a "hit" or a match each time a key word or phrase was found within the mission statement. A listing of all mission statements containing the key words was displayed for further analysis. Each mission statement could be displayed with the key words highlighted in context. This capability proved important in refining the key word lists for each mission element by permitting the programmer/author to examine whether the key words were operating consistently with the conceptual definition of each element. An iterative process of defining the key words, testing them on sample mission statements and refining the key words was used to improve the content analysis capabilities.

The content analysis approach via computer was validated by analyzing the mission statements contained in David (1991) and comparing the computerized results to those obtained by independent judges. The judges were six graduating MBA students who had completed the capstone course in Strategic Management/Business Policy. The students were given the Pearce and David article (1987) outlining the evaluation 
Table 1

Validation of Computerized Content Analysis With Comparision to Coding by a Panel of Six MBA Students

\begin{tabular}{|l|c|c|c|}
\hline & \multicolumn{2}{|c|}{$\begin{array}{c}\text { Coefficient of Concordance for Mission } \\
\text { Elements coded by MBS Students }\end{array}$} & $\begin{array}{c}\text { Compariston of } \\
\text { Computerized } \\
\text { Analysis vs. } \\
\text { MBA Student } \\
\text { Analysis }\end{array}$ \\
\hline $\begin{array}{c}\text { MISSION } \\
\text { ELEMFNT }\end{array}$ & KENDALL'S W & CHI-SQUARE & $\begin{array}{c}\text { Pcarson } \\
\text { Correlation } \\
\text { Coeficients }\end{array}$ \\
\hline Customer & .5722 & $20.6000^{* *}$ & $.7303^{*}$ \\
\hline Products & .5298 & $19.0714^{* *}$ & $.6455^{*}$ \\
\hline Geographic Domain & .7813 & $28.1250^{* * *}$ & $.7303^{*}$ \\
\hline Technology & .4400 & $15.8400^{* *}$ & $.7500^{*}$ \\
\hline $\begin{array}{l}\text { Survival, Growth } \\
\& \text { Profitabiltiy }\end{array}$ & .5161 & $18.5806^{* *}$ & $.5477^{*}$ \\
\hline Company Philosophy & .3016 & $10.8570^{* *}$ & -.0167 \\
\hline Self- Image & .5179 & $18.6429^{* *}$ & $.6455^{*}$ \\
\hline Public Image & .5402 & $19.4483^{* *}$ & $1.0000^{* * *}$ \\
\hline
\end{tabular}

$* \mathrm{p}<10$

** $\mathrm{p}<.05$

*** $\mathrm{p}<.001$

criteria and a packet of the word-processed mission statements. They were instructed to read the article and to independently score each mission statement using the same criteria and procedures as in the article. The instructions further required students to read and complete their evaluation of each mission statement before proceeding to the next. They were also asked not to discuss their evaluations with any of the other students participating in the project. The mission statements were sorted randomly in the packets to avoid any biases due to the order in which they were evaluated.

Kendall's W (coefficient of concordance) was run to show the extent to which the six coders agreed on the evaluation of the mission statements. Kendall's W for each mission element is shown in Table 1. 
The coefficients of concordance ranged from a low of $\mathrm{W}=.3016$ for the company philosophy mission element to a high of $\mathrm{W}=.7813$ for the geographic domain mission element. The chi-square statistic was statistically significant at the .01 level or better for six of the eight mission elements. The chi-square for the technology element was significant at the .05 level while the chi-square for the company philosophy element was moderately significant at the .10 level. Statistically significant chi-squares indicate a high level of agreement between coders on the evaluation of each of the elements of the mission statements.

For the remainder of the analysis, the evaluations of the student coders were aggregated according to a procedure used in D'Aveni and MacMillan (1990), David (1989b), David and Cochran (1986) and Pearce and David (1987). Mission statements were coded as containing an element if at least four of the six coders indicated that the statement referred to that specific element.

Pearson correlation coefficients comparing the results of the computerized analysis of the mission statements with those obtained by the panel of six MBA students are presented in the fourth column of Table 1 . As indicated by the significant and positive correlation coefficients, the two methods of content analysis reached substantially the same conclusions for the customer, products, geographic domain, technology, survival, self image and public image mission elements thus validating the computerized approach. Only the score for the company philosophy element was not significantly related between the computerized and human coding methodologies. Despite additional iterations of the development and testing process, development of a key word list which adequately represented the intent of the company philosophy element proved elusive. The company philosophy element was omitted from subsequent analyses due to the problems in the content analysis of this element. ${ }^{4}$ The computerized content analysis approach was utilized in all subsequent coding of company documents.

Performance measures. Due to the desire to produce results which could be directly compared with those of Pearce and David (1987), each firm's profit margin was used. In addition, financial performance measures such as return on assets (ROA) and return on equity (ROE) were included in the study. Measures for profit margin, ROA and ROE for the years 1988, 1989 and 1990 were used to eliminate biases introduced by temporary aberrations in financial performance. None of these variables were averaged in the subsequent analysis, but were treated as multiple dependent variables in the MANOVA analysis. Separate MANOVA analyses were independently completed for each group of performance variables, thus permitting an examination of differences in the results due to differences in the performance variables themselves. The details of the MANOVA analyses will be explained in a later section.

Summary of Study Variables. Each firm in the sample was classified into one of the following four levels of diversification according to the method described earlier: single product firms, dominant product firms, related diversified firms, or unrelated diversified firms. The annual reports of the firms were examined via computerized content analysis for the presence or absence of eight attributes associated with mission statements. These attributes or elements included: customers, products, geo- 
Tahle 2: INTER.ITEM CORRELATIONS FOR STUDY YARIARLES

YARIABLE CUST PROD GEO TECH SURV SELF PUB EMP DIV PM88 PM89 PM90 ROA88 ROA89 ROA90 ROE88 ROE89 ROE90 Mission Variable:

\begin{tabular}{|c|c|c|c|c|c|c|c|c|c|c|c|c|c|c|c|c|c|c|}
\hline $\begin{array}{l}\text { Customer } \\
\end{array}$ & 1.0000 & & & & & & & & & & & & & & & & & \\
\hline Product & .6864 & 1.0000 & & & & & & & & & & & & & & & & \\
\hline $\begin{array}{l}\text { Geo. } \\
\text { Domain }\end{array}$ & .5132 & .6251 & 1.0000 & & & & & & & & & & & & & & & \\
\hline Technolgy & .7271 & $\begin{array}{c}.6225 \\
* * *+\end{array}$ & .7317 & 1.0000 & & & & & & & & & & & & & & \\
\hline $\begin{array}{l}\text { Survival, } \\
\text { Growth }\end{array}$ & \begin{tabular}{|l|}
.5519 \\
$-5 \% *$ \\
\end{tabular} & .3605 & .3281 & .4051 & 1.0000 & & & & & & & & & & & & & \\
\hline Self-Image & .59000 & .6489 & .6206 & $\begin{array}{c}.7346 \\
. * * \\
\end{array}$ & $\begin{array}{l}.5736 \\
* * * \\
\end{array}$ & 1.0000 & & & & & & & & & & & & \\
\hline $\begin{array}{l}\text { Public } \\
\text { Image }\end{array}$ & .2205 & $\begin{array}{ll}.2822 \\
* 4\end{array}$ & .1982 & .0711 & \begin{tabular}{|l|}
.4148 \\
$\cdots * *$ \\
\end{tabular} & .4191 & 1.0000 & & & & & & & & & & & \\
\hline Employees & .2766 & .2073 & .2510 & .0735 & .2651 & .2743 & .1653 & 1.0000 & & & & & & & & & & \\
\hline \multicolumn{19}{|c|}{ Diversification Variable: } \\
\hline $\begin{array}{l}\text { Level of } \\
\text { Diversification }\end{array}$ & .0335 & .0799 & .1303 & .3658 & $\begin{array}{l}.1194 \\
* * * \\
\end{array}$ & .2308 & .0550 & .2392 & 1.0000 & & & & & & & & & \\
\hline \multicolumn{19}{|c|}{\begin{tabular}{|l|l|l|l|l|l|l|} 
Performance Variahless & & & & \\
\end{tabular}} \\
\hline $\begin{array}{l}\text { Profit Margin } \\
1988\end{array}$ & -.0203 & -.0541 & .0146 & .2796 & -.0549 & -.0277 & -.0443 & .0120 & -.0236 & 1.0000 & & & & & & & & \\
\hline $\begin{array}{l}\text { Profit Margin } \\
1989\end{array}$ & -.0457 & .0992 & .0007 & .2511 & -.0452 & -.0508 & -.0366 & -.0008 & -.0105 & $\begin{array}{l}.9333 \\
* * * \\
\end{array}$ & 1.0000 & & & & & & & \\
\hline $\begin{array}{l}\text { Profit Margin } \\
1990\end{array}$ & .0148 & -.0715 & .0158 & $\begin{array}{l}.2845 \\
. * * \\
\end{array}$ & -.0270 & -.0267 & -.0194 & .0011 & -.0069 & .9208 & \begin{tabular}{|c|}
9554 \\
$\cdots$
\end{tabular} & 1.0000 & & & & & & \\
\hline \begin{tabular}{|l|} 
ROA 1988 \\
ROA 1989
\end{tabular} & .0868 & -.0081 & .0559 & .08829 & .0257 & -.0302 & .1187 & .0299 & .0924 & .0683 & -.0354 & .0102 & 1.0000 & & & & & \\
\hline & $-.1169 \mid$ & -.0743 & -.0319 & -.1371 & -.0169 & .0630 & .1189 & .0083 & .0181 & -.0691 & -.0354 & -.0213 & \begin{tabular}{|l|l|}
.8627 \\
$* * *$ \\
\end{tabular} & 1.0000 & & & & \\
\hline ROA 1990 & -.0625 & .0476 & -.1309 & -.1825 & .0542 & .0608 & .0271 & .0318 & .0015 & -.1283 & -.1439 & $\begin{array}{r}-.1475 \\
.\end{array}$ & .4390 & $\begin{array}{l}.5027 \\
* * * \\
\end{array}$ & 1.0000 & & & \\
\hline ROE 1988 & .0813 & .0928 & -.0093 & -.2800 & .0172 & -.1094 & -.0235 & -.0223 &. .1469 & -.0784 & -.0606 & -.0323 & .0675 & -.0226 & .0945 & 1.0000 & & \\
\hline ROE 1989 & -.0915 & .0446 & -.0071 & .1654 & .0341 & -.0176 & .0902 & .1166 & -.0060 & -.0337 & -.0301 & .0417 & .2728 & .1586 & .1303 & -.1311 & 1.0000 & \\
\hline ROE 1990 & .0379 & .0209 & .0008 & .0930 & -.0343 & .0192 & -.0892 & .1263 & .0585 & .0150 & .0158 & .0095 & .3704 & .1834 & .3732 & .0721 & .3800 & 1.0000 \\
\hline
\end{tabular}

* $p<.10, \cdots p<.05, * * * p<.01$

* For mission variables, a mean value of 1.00 indicates that all firms included this element in their mission statements. Level of diversification was coded as

$1=$ single-product firm, $2=$ dominant product firm, $3=$ related diversification, $4=u n r e l a t e d$ diversification. 
graphic domain, technology, concern for survival, self-concept, public image and employees. Finally, to permit the examination of the relationship of mission statement components to financial performance, profit margins, ROAs and ROEs for three years were included in the data set. The means, standard deviations and inter-correlation matrix are provided as Table 2 .

\section{Discussion of Findings}

Analysis of variance was used to determine if there were differences in the mix of elements included in the mission statements of firms following different diversification strategies, thus addressing the issues presented in the first research question. Means and standard deviations for each mission element are shown for the four levels of diversification (single, dominant, related and unrelated) in Table 3. A series of one-way analyses of variances were run to determine if significant differences existed in the inclusion of each of the mission elements by level of diversification. Significant differences (at the .05 level or better) between the four levels of diversification were found for the customer, technology, and self-image mission elements. The concern for employees mission element was marginally significant at the $\mathrm{p}<.10$ level. No significant difference was observed in the other four mission elements.

Table 3

Means, Standard Deviations and Sample Size

For Firm by Level of Diversification

\begin{tabular}{|l|c|c|c|c|}
\hline & $\begin{array}{l}\text { Single } \\
\text { Product } \\
\text { Mission Element }\end{array}$ & $\begin{array}{c}\text { Dominant } \\
\text { Product } \\
\text { Firms }\end{array}$ & $\begin{array}{c}\text { Related } \\
\text { Diversified } \\
\text { Firms }\end{array}$ & $\begin{array}{l}\text { Unrelated } \\
\text { Diversified } \\
\text { Firms }\end{array}$ \\
\hline Customers & $.8462^{\mathrm{a}}$ & .7500 & .6944 & .7778 \\
& $(.4249)$ & $(.4376)$ & $(.4672)$ & $(.4278)$ \\
\hline Products & .8974 & .8333 & .8889 & .9444 \\
& $(.3268)$ & $(.3766)$ & $(.3187)$ & $(.2357)$ \\
\hline Geographic & .8305 & .8125 & .8056 & .9444 \\
Domain & $(.3888)$ & $(.3944)$ & $(.4014)$ & $(.2357)$ \\
\hline Technology & .3077 & .2500 & .4444 & .6111 \\
& $(.4676)$ & $(.4376)$ & $(.5040)$ & $(.5016)$ \\
\hline Survival, Growth & .7692 & .8333 & .7500 & .8889 \\
$\&$ Profitability & $(.4268)$ & $(.3766)$ & $(.4392)$ & $(.3234)$ \\
\hline Self-Image & .9231 & .8958 & .9167 & .9444 \\
& $(.2700)$ & $(.3087)$ & $(.2803)$ & $(.2357)$ \\
\hline Public Image & .6154 & .7083 & .4722 & .6667 \\
& $(.4929)$ & $(.4593)$ & $(.5063)$ & $(.4851)$ \\
\hline Employees & .4615 & .3958 & .5278 & .6667 \\
& $(.5050)$ & $(.4942)$ & $(.5063)$ & $(.4851)$ \\
\hline \multicolumn{1}{|c|}{$\mathrm{n}$} & 39 & 48 & 36 & 18 \\
\hline
\end{tabular}

- Mean values and standard diviations in parenthesis. A mean of 1.000 indicates that all firms in the cell included this element in their mission statements 
When significant differences in the inclusion of the mission elements by level of diversification were indicated in the one-way analysis of variance, the Scheffe multiple comparison test was run to pinpoint the differences between groups. Of the multiple comparison tests, the Scheffe method provides for the most conservative comparison of means (Keppel, 1982). This analysis was performed to address the issues presented by the second research question which sought an explanation of how the mission statements of more diversified firms differed from those of less diversified firms.

Customers. For the customers mission element, the Scheffé test indicated that the mean rate of inclusion for the related diversification firms was significantly different (at $p<.05$ ) from the means for the single-product and unrelated diversification firms. Both the single-product and unrelated diversification firms were more likely to include a discussion of the firm's target customers than the firms following a related diversification strategy. The finding for single-product firms is not surprising. One would expect that because single product firms are obtaining the largest percentage of their revenues from a single product/market activity, specification of target customers would be an important part of defining the strategic focus for single-product firms. However, the finding that unrelated diversified firms were more likely to include a discussion of target customers in their missions than firms following a related diversification strategy is somewhat counter-intuitive. One might expect that the more diversified a firm becomes and the more unrelated the diversification, the more difficult it would become to define exactly who the customers of the firm are. For firms following an unrelated diversification strategy, specification of target customers may be a means for effectively elaborating the various business interests of the firms. Rather than serving as a unifying element of the mission, unrelated diversified firms may use descriptions of the firms target customers to describe the diversity of its mission.

Products or Services. No statistical difference was found in the rate of inclusion of a statement of products or services in the missions of firms at different levels of diversification. In fact, at least half of the firms in each diversification category included this component in their missions. The mean for the unrelated diversification firms was greater than the mean for any other level of diversification but not significantly so. These findings support Pearce's claim that description of the company's basic products or services is an indispensable component of the mission statement (Pearce, 1982: 17). The significance of the products element for all firms is also demonstrated by the importance of the products a firm makes to its corporate identity with outsiders such as investors and competitors.

Geographic Domain. Specification of a firm's geographic domain in the mission statement was also expected to differ at different levels of diversification, with unrelated diversification firms less likely to include a description of their target geographic markets. As the firm becomes more diversified, different geographic domains may apply to each of the firm's different product/market divisions. As the number of different geographic domains served by the various divisions of a firm increased, the expectation was that the firm would be less likely to include this element in its mis- 
sion statement due to the complexities it posed. However, no significant difference was observed in the geographic domain means between diversification levels. In fact, firms at all levels of diversification were more likely to include a description of geographic domain in their mission statements than other mission elements such as technology, public image and employees. This may be due in part to the increased emphasis on international business in the 1990's. Firms that were doing business internationally may have felt it beneficial to identify their geographic markets.

Technology. Inclusion of the technology element was expected to vary with different levels of diversification. More diversified firms were expected to have difficulties in describing the various technologies utilized, especially as they began to diversify in unrelated areas. The Scheffé results indicate just the opposite. No significant difference was observed in the mean rate of inclusion of the technology component for the single-product, dominant product or related diversification firms. The rate of inclusion of the technology element in unrelated diversification firms was significantly greater than for all other levels of diversification. As found in Pearce and David (1987), the technology element was less frequently included in the mission statements than the other mission elements. However, the tendency of unrelated diversification firms in this sample to more frequently include the technology element than firms with lower levels of diversification contradicts the rationale given in Pearce and David (1987). Responses to their follow-up questions indicated that many firms did not incorporate the technology element in their missions due to the impossibility of describing the diverse technologies on which the firm's multiple products depended. A possible explanation may be that in seeking to provide a sense of unified purpose, firms following an unrelated diversification strategy are more likely to find the common thread through similarities in technology than through products or customers. Thus, although classified as unrelated diversified firms using the more product-oriented definition based on specialization ratios and related ratios, the firms may have technological processes in common and emphasize them in their missions. This makes some sense especially in light of Pearce's (1991) assertion that the products, geographic domain and technology components were indispensable in describing a firm's business activity. If unrelated diversified firms do not have commonalties in their products or primary markets, relationships (however slight) between the technologies of divisions may be the only way to provide a common focal point for future strategies.

Commitment to Survival, Growth \& Profitability. Since survival, growth and profitability are mainstay goals of almost every business organization (Pearce, 1991), the level and type of diversification were not expected to influence the inclusion or exclusion of this element from a firm's mission. No difference in commitment to survival, growth and profitability was predicted for firms at different levels of diversification. The results of the one-way analysis of variance supported this prediction. All firms were equally likely to include language expressing their commitment to the firm's continued survival, growth and profitability in the letters to the stockholders. Although the mean rate of inclusion for this element appears greater for unrelated diversifications, the difference in means was not significant. 
Self-image. A firm's self-image reflects a self-assessment of competitive strengths and weaknesses. The ability of a firm to perform a realistic self-diagnosis is crucial to firm success regardless of its complexity due to diversification. However, significant differences were observed between firms at different levels of diversification when referring to the self-image mission element. The Scheffé test indicated a significant difference in the mean rate of inclusion of the element between the unrelated diversification firms and the dominant product or related diversification firms. The mean for the single-product firms was not significantly different from those of firms employing different diversification strategies.

Firms following an unrelated diversification strategy were more likely to include statements identifying their competitive strengths and weaknesses (their self-image) than firms following either related diversification or dominant-product strategies. One possible explanation for this seemingly contradictory finding may be that unrelated diversified firms may be trying to compensate for the supposed disadvantages of the "unrelatedness" of their businesses by explicitly stating and drawing attention to their competitive strengths. Current trends toward related diversification as a superior strategy tend to support this explanation.

Public image. The public image mission element addresses the qualities which are attributed to the firm by customers, suppliers, creditors and other external entities. Inclusion of a firm's desired public image in its mission provides outsiders with a statement of the firm's future intentions to remain true to those qualities the public has come to associate with the firm. It was expected that all firms would express their desired public image in their mission statements and that this expression would not differ with regard to the level of diversification. This prediction was supported by the one-way analysis of variance. No significant difference in the rate of inclusion of the public image element was observed for the different levels of diversification.

Although all firms were equally likely to include this element, concern for public image was included less frequently than many of the other mission elements. Only 24\% of the 141 firms in this study included this element in their mission statements while $87 \%$ of Pearce and David's (1987) firms expressed their desired public image. The smaller percentage of firms including public image in this study may be due to differences in environmental stresses encountered by the firms at the time the samples were collected for this study and the Pearce and David (1987) study. During times when corporate legitimacy and responsibility is challenged by outsiders, firms may be compelled to include more public image verbiage to reemphasize or stress the firm's beneficial aspects.

Concern for Employees. The concern for employees mission element recognizes the employees of the firm as valuable assets instrumental to achievement of organizational goals. This recognition appears to be equally important to all firms whether they are single-product or diversified firms. This prediction was not supported by the results of the one-way analysis of variance or the Scheffé multiple comparisons procedure. Firms that followed an unrelated diversification strategy were more likely to 
include a discussion of the importance of employees than single-product firms. Only $5 \%$ of the single-product firms included a discussion of employees while almost $28 \%$ of the unrelated diversification firms discussed the importance of employees to firm goal attainment. The inclusion percentages appear to be the reverse of what one would expect although unrelated diversification firms might view concern for employees as a potential rallying point for unifying their diverse interests. By emphasizing a commitment to value the employees and their contributions to the firm, the unrelated diversification firm may be trying to motivate and inspire employees to achieve corporate goals.

In addressing the third research question, multivariate analysis of variance (MANOVA) was used to examine the relationship of the mission statement elements to level of diversification and firm financial performance. MANOVA is used to assess the statistical significance of differences between groups across multiple dependent variables simultaneously. MANOVA provides better statistical control over the experiment-wide error rate than use of separate univariate ANOVAs as well as a more powerful examination of differences in group means of the multiple dependent variables (Hair, Anderson, Tatham \& Black, 1992).

Three separate dependent variables sets were evaluated in separate MANOVAs: profit margins for 1988-1990, ROAs for 1988-1990 and ROEs for 1988-1990. ${ }^{5}$ A series of MANOVAs were run using one of the performance variable sets as the dependent variables and each mission statement element and the four levels of diversification as the independent variables. This resulted in a $2 \times 4$ design for each mission element: the mission element was included or not included in the firm's letter to shareholders and the firm was either a single-product, dominant-product, related diversified or unrelated diversified firm. Since a requirement of MANOVA is that the dependent variables included in the analysis be correlated, the appropriateness of the multivariate technique was tested by Bartlett's test of sphericity (Cooley \& Lohnes, 1971). The test was significant at $\mathrm{p}<.001$ for all three performance variable sets thus indicating that MANOVA is appropriate for analyzing the data.

Although all of the eight cells in the research design contained firms, the Ns in the cells were unequal. As a result, a QR approach was used in the MANOVA model. The QR approach is used in unbalanced MANOVA designs to eliminate the confounding influence of other factors when testing each effect. The QR approach in SPSS-X estimates parameters using Householder transformations to effect an orthogonal decomposition of the design matrix.

Table 4 shows the results of the MANOVAs of the three performance measure vectors by each of the eight mission elements and the level of diversification. Significant interactions between the mission element (m) and level of diversification (d) (interaction represented by $\mathrm{m} \times \mathrm{d}$ ), were observed for the customer, geographic domain, survival, self-image and public image mission elements. No significant interactions or main effects were observed for the products and employees mission elements. A significant overall main effect was found for the technology mission element. The presence of significant interaction terms indicate that for at least some of the mission 


\section{F-Ratio and Level of Significance for Manova Main Effects and Interaction Terms (1)}

Examination of Differences in the Relationship of Mission Element Inclusion to Financial Performance

\begin{tabular}{|c|c|c|c|c|c|c|c|c|}
\hline $\begin{array}{l}\text { Source of Variation } \\
\text { Performance Variables }\end{array}$ & Customers & Products & $\begin{array}{l}\text { Geographic } \\
\text { Domain }\end{array}$ & Technology & $\begin{array}{l}\text { Survival, } \\
\text { Growth \& } \\
\text { Profitabiltiy }\end{array}$ & $\begin{array}{l}\text { Self- } \\
\text { Image }\end{array}$ & $\begin{array}{l}\text { Public } \\
\text { Image }\end{array}$ & Employee \\
\hline \multicolumn{9}{|l|}{ MISSION ELEMENT (m) } \\
\hline Profit Margin 1988-1990 & $5.29221 * * *$ & 1.14176 & 1.78432 & $2.26839^{*}$ & 1.55455 & 1.65435 & .18609 & 1.49419 \\
\hline ROA 1988-1990 & $2.39621^{*}$ & .26915 & .60946 & .25399 & 1.32416 & .05014 & .54165 & .16377 \\
\hline ROE 1988-1990 & $2.70647^{*}$ & .35680 & .09198 & 1.98698 & 1.65725 & .48705 & 1.60490 & .40806 \\
\hline \multicolumn{9}{|l|}{$\begin{array}{l}\text { LEVEL of } \\
\text { DIVERSIFICATION (d) }\end{array}$} \\
\hline Profit Margin & $1.97751^{* *}$ & .74927 & $1.83181^{*}$ & .90844 & $2.43930^{* * *}$ & $2.29522^{* *}$ & 1.09792 & 1.04507 \\
\hline ROA 1988-1990 & $2.16938^{* *}$ & .37145 & .78105 & .32322 & $1.98761^{* *}$ & .70893 & 1.14157 & .49104 \\
\hline ROE 1988-1990 & $1.62905^{*}$ & .84528 & .44891 & 1.15559 & .65576 & .23299 & 1.34852 & 1.43201 \\
\hline \multicolumn{9}{|l|}{$\mathrm{m} x \mathrm{~d}$ INTERACTION } \\
\hline Profit Margin 1988-1990 & $2.82035 * * *$ & 1.19006 & $1.75882^{*}$ & .41453 & $2.10264^{* *}$ & $3.25708 * * *$ & 1.24155 & .41319 \\
\hline ROA 1988-1990 & $2.60669 * * *$ & .46084 & .66896 & .74691 & $2.14997^{* *}$ & .64045 & $1.96014^{* *}$ & .89370 \\
\hline ROE 1988-1990 & 1.35020 & .50447 & .25336 & .74340 & .64144 & .26752 & 1.32177 & 1.28594 \\
\hline df & 3,128 & 3,128 & 3,128 & 3,128 & 3,128 & 3,128 & 3,128 & 3,128 \\
\hline
\end{tabular}

Significance levels denoted as:

$$
\begin{aligned}
& * \quad p<.10 \\
& * * \quad p<.05 \\
& * * * \quad p<.01
\end{aligned}
$$

(1) Each column of the table represents a separate MANOVA analysis with dependent variables of three years of the performance variables. (Profit margin, ROA, ROE). Independent variables were the mission element (either present or absent) and the level of diversification (single-product, dominant product, related diversification, unrelated diversification). 
elements, the inclusion or exclusion of the element in the mission was contingent upon the firm's level of diversification and financial performance. This finding lends support to the argument against universal mission content regardless of strategic context.

The nature of the interactions may be interpreted through multivariate tests of simple effects (Bray \& Maxwell, 1990). A second set of MANOVAs was conducted for the five mission elements with significant interaction terms. In these MANOVAs, the dependent variables were again the three measures of profit margin 1988-1990, ROA 1988-1990 or ROE 1988-1990. The independent variable was the mission element to be analyzed (either included or excluded). An independent MANOVA was conducted for each level of diversification. The univariate and multivariate results of these analyses are summarized in Tables 5 through 7.

By conducting an independent MANOVA of each mission element by each level of diversification, the mission element effects can be analyzed and interpreted in the context of the interactive effects of the level of diversification factor.

For the customer mission element, significant multivariate effects are observed for single-product and unrelated diversified firms when profit margin or ROA was used as the dependent variables (Table 5). No significant multivariate or univariate results were observed for dominant product. A significant univariate result was observed for related diversified firms when the ROA for 1988 was the dependent variable. With this exception, for firms following a dominant product or related diversification strategy, the inclusion or exclusion of the customer element in the firm's mission did not have an effect on the firm's financial performance.

An examination of the univariate F-ratios for single-product firms reveals that while the inclusion of the customer element has a significant effect on the multivariate profit margin measure, no significant difference is observed for the univariate profit margin measures. The profit margin means for each year are not significantly different between single-product firms that included or did not include the customer element in their mission. When ROA is considered, single-product firms including the customer element in their missions earned a significantly higher ROA in 1988 than firms who did not discuss customers in their mission. Single-product firms that included the customer element in their missions earned an average ROA of $3.7 \%$ in 1988 (STD $\mathrm{DEV}=.069$ ) as compared to an average ROA of $-8.5 \%$ (STD DEV =.320) for single-product firms that did not mention their customers. No statistical difference was observed in the ROAs for 1989 and 1990 of single-product firms regardless of whether the customer element was included. Although focus on customers seems consistent with superior financial performance, it is difficult to determine a specific explanation for the 1988 results without additional information regarding economic and other environmental conditions of that time period. An increased customer orientation for single-product firms in this sample appears to have been favored by industry and general environmental conditions prevalent in 1988.

For related diversified firms in 1988, a moderately significant F-ratio was observed for the relationship between inclusion of the customer element and firm performance 
Table 5

Summary of Importance of Customer Mission Element

Multivariate and Univariate Analysis of Variance,

Means and Standard Deviations

By Level of Diversification

\begin{tabular}{|c|c|c|c|c|c|c|c|c|c|c|c|c|}
\hline \multirow[b]{2}{*}{$\begin{array}{l}\text { Performance } \\
\text { Variables }\end{array}$} & \multicolumn{3}{|c|}{$\begin{array}{c}\text { Single } \\
\text { Product Firms }\end{array}$} & \multicolumn{3}{|c|}{$\begin{array}{l}\text { Dominant } \\
\text { Product Firms }\end{array}$} & \multicolumn{3}{|c|}{$\begin{array}{c}\text { Related } \\
\text { Diversified Firms }\end{array}$} & \multicolumn{3}{|c|}{$\begin{array}{c}\text { Unrelated } \\
\text { Diversified Firms }\end{array}$} \\
\hline & $\begin{array}{c}\text { F-Ratio } \\
\& \\
\text { Signif. } \\
\text { Levels }\end{array}$ & $\begin{array}{l}\text { Customer } \\
\text { Not } \\
\text { Included }\end{array}$ & $\begin{array}{l}\text { Customer } \\
\text { Included }\end{array}$ & $\begin{array}{c}\text { F-Ratio } \\
\& \\
\text { Signif. } \\
\text { Levels }\end{array}$ & $\begin{array}{c}\text { Customers } \\
\text { Not } \\
\text { Included }\end{array}$ & $\begin{array}{l}\text { Customer } \\
\text { Included }\end{array}$ & $\begin{array}{l}\text { F-Ratio } \\
\& \\
\text { Signif. } \\
\text { Levles }\end{array}$ & $\begin{array}{l}\text { Custome } \\
\text { Not } \\
\text { Included }\end{array}$ & $\begin{array}{l}\text { Customer } \\
\text { Included }\end{array}$ & $\begin{array}{c}\text { F-Ratio } \\
\& \\
\text { Signif. } \\
\text { Levels }\end{array}$ & $\begin{array}{l}\text { Customer } \\
\text { Not } \\
\text { Inlcuded }\end{array}$ & $\begin{array}{l}\text { Customer } \\
\text { Included }\end{array}$ \\
\hline $\begin{array}{l}\text { Multivariate } \\
\text { Profit Margin: }\end{array}$ & $\begin{array}{l}2.86067 \\
p<.051\end{array}$ & & & $\begin{array}{l}1.08384 \\
p<.366\end{array}$ & & & $\begin{array}{l}1.61867 \\
p<.206\end{array}$ & & & $\begin{array}{l}1.28409 \\
p<.011\end{array}$ & & \\
\hline $\begin{array}{l}\text { Profit Margin } \\
\text { 1988: }\end{array}$ & $\begin{array}{r}.60051 \\
p<.443\end{array}$ & $\begin{array}{c}.444^{2} \\
(.141)\end{array}$ & $\begin{array}{c}.382 \\
(.187)\end{array}$ & $\begin{array}{r}1.13344 \\
\mathrm{p}<.293\end{array}$ & $\begin{array}{c}.409 \\
(.200)\end{array}$ & $\begin{array}{c}.470 \\
(.162)\end{array}$ & $\begin{array}{l}.26268 \\
p<.612\end{array}$ & $\begin{array}{r}.407 \\
(.125)\end{array}$ & $\begin{array}{r}.373 \\
(.200)\end{array}$ & $\begin{array}{l}10.52398 \\
p<.005\end{array}$ & $\begin{array}{r}.649 \\
(.041) \\
\end{array}$ & $\begin{array}{l}.320 \\
(.197)\end{array}$ \\
\hline $\begin{array}{l}\text { Profit Margin } \\
\text { 1989: }\end{array}$ & $\begin{array}{l}1.46827 \\
p<.982\end{array}$ & $\begin{array}{l}.478 \\
(.229)\end{array}$ & $\begin{array}{l}.378 \\
(.178)\end{array}$ & $\begin{array}{l}1.90963 \\
p<.174\end{array}$ & $\begin{array}{c}.379 \\
(.165)\end{array}$ & $\begin{array}{c}.457 \\
(.168)\end{array}$ & $\begin{array}{c}.04912 \\
\mathrm{p}<.826\end{array}$ & $\begin{array}{l}.414 \\
(.124)\end{array}$ & $\begin{array}{c}.398 \\
(.226)\end{array}$ & $\begin{array}{l}10.18811 \\
p<.006\end{array}$ & $\begin{array}{c}.631 \\
(.069)\end{array}$ & $\begin{array}{r}.312 \\
(.192)\end{array}$ \\
\hline $\begin{array}{l}\text { Profit Margin } \\
\text { 1990: }\end{array}$ & $\begin{array}{l}.000051 \\
p<.982\end{array}$ & $\begin{array}{l}.380 \\
(.178) \\
\end{array}$ & $\begin{array}{l}.382 \\
(.192) \\
\end{array}$ & $\begin{array}{l}1.42471 \\
\mathrm{p}<.239\end{array}$ & $\begin{array}{l}.385 \\
(.174) \\
\end{array}$ & $\begin{array}{c}.456 \\
(.180) \\
\end{array}$ & $\begin{array}{l}.00146 \\
p<.970\end{array}$ & $\begin{array}{r}.396 \\
(.134) \\
\end{array}$ & $\begin{array}{r}.399 \\
(.228) \\
\end{array}$ & $\begin{array}{l}7.88715 \\
\mathrm{p}<.013\end{array}$ & $\begin{array}{c}.605 \\
(.099) \\
\end{array}$ & $\begin{array}{r}.313 \\
(.197) \\
\end{array}$ \\
\hline $\mathrm{n}$ & & 6 & 32 & & 12 & 35 & & 11 & 23 & & 4 & 13 \\
\hline $\begin{array}{l}\text { Multivariate } \\
\text { ROA: }\end{array}$ & $\begin{array}{l}3.88500 \\
\mathrm{p}<.017\end{array}$ & & & $\begin{array}{l}1.66522 \\
p<.188\end{array}$ & & & $\begin{array}{l}1.69950 \\
p<.193\end{array}$ & & & $\begin{array}{l}2.53839 \\
p<.099 \\
\end{array}$ & & \\
\hline ROA 1988: & $\begin{array}{l}4.21935 \\
p<.047\end{array}$ & $\begin{array}{r}-.085 \\
(.320) \\
\end{array}$ & $\begin{array}{c}.037 \\
(.069)\end{array}$ & $\begin{array}{l}.03628 \\
p<.850\end{array}$ & $\begin{array}{l}.057 \\
(.060)\end{array}$ & $\begin{array}{c}.049 \\
(.131) \\
\end{array}$ & $\begin{array}{l}3.60116 \\
p<.066\end{array}$ & $\begin{array}{c}.029 \\
(.042) \\
\end{array}$ & $\begin{array}{c}.064 \\
(.054) \\
\end{array}$ & $\begin{array}{l}8.66912 \\
p<.010\end{array}$ & $\begin{array}{c}.061 \\
(.051) \\
\end{array}$ & $\begin{array}{l}-.023 \\
(.046) \\
\end{array}$ \\
\hline ROA 1989: & $\begin{array}{r}.79237 \\
p<.379\end{array}$ & $\begin{array}{r}.012 \\
(.186) \\
\end{array}$ & $\begin{array}{l}.048 \\
(.064)\end{array}$ & $\begin{array}{l}.51170 \\
p<.478\end{array}$ & $\begin{array}{l}.040 \\
(.067)\end{array}$ & $\begin{array}{l}.069 \\
(.135)\end{array}$ & $\begin{array}{l}2.04994 \\
p<.161\end{array}$ & $\begin{array}{c}.034 \\
(.037)\end{array}$ & $\begin{array}{l}.063 \\
(.063)\end{array}$ & $\begin{array}{l}5.10688 \\
\mathrm{p}<.038\end{array}$ & $\begin{array}{c}.060 \\
(.054) \\
\end{array}$ & $\begin{array}{l}-.033 \\
(.010) \\
\end{array}$ \\
\hline ROA 1990: & $\begin{array}{l}.34599 \\
p<.560\end{array}$ & $\begin{array}{l}.065 \\
(.057)\end{array}$ & $\begin{array}{l}.047 \\
(.057)\end{array}$ & $\begin{array}{l}.53424 \\
\mathrm{p}<.469\end{array}$ & $\begin{array}{l}.063 \\
(.073)\end{array}$ & $\begin{array}{l}.048 \\
(.053)\end{array}$ & $\begin{array}{r}.27409 \\
\mathrm{p}<.604\end{array}$ & $\begin{array}{c}.040 \\
(.040)\end{array}$ & $\begin{array}{c}.051 \\
(.065)\end{array}$ & $\begin{array}{l}4.17416 \\
p<.058\end{array}$ & $\begin{array}{c}.064 \\
(.052)\end{array}$ & $\begin{array}{l}.010 \\
(.008)\end{array}$ \\
\hline $\mathrm{n}$ & & 6 & 33 & & 12 & 36 & & 11 & 25 & & 4 & 14 \\
\hline
\end{tabular}

- Mean for the performance variable. Standard deviation given in parenthesis 
Table 6

Summary of Importance of Geographic Domain Mission Element,

Multivariate and Univariate Analysis of Variance,

Means and Standard Deviations

By Level of Diversification

\begin{tabular}{|c|c|c|c|c|c|c|c|c|c|c|c|c|}
\hline \multirow[b]{2}{*}{$\begin{array}{l}\text { Performance } \\
\text { Variables }\end{array}$} & \multicolumn{3}{|c|}{$\begin{array}{c}\text { Single } \\
\text { Product Firms }\end{array}$} & \multicolumn{3}{|c|}{$\begin{array}{l}\text { Dominant } \\
\text { Product Firms }\end{array}$} & \multicolumn{3}{|c|}{$\begin{array}{c}\text { Related } \\
\text { Diversified Firms }\end{array}$} & \multicolumn{3}{|c|}{$\begin{array}{c}\text { Unrelated } \\
\text { Diversified Firms }\end{array}$} \\
\hline & $\begin{array}{c}\text { F-Ratio } \\
\& \\
\text { Signif. } \\
\text { Levels }\end{array}$ & $\begin{array}{c}\text { Domain } \\
\text { Not } \\
\text { Included }\end{array}$ & $\begin{array}{l}\text { Domain } \\
\text { Included }\end{array}$ & $\begin{array}{l}\text { F-Ratio } \\
\& \\
\text { Signif. } \\
\text { Levels }\end{array}$ & $\begin{array}{c}\text { Domain } \\
\text { Not } \\
\text { Included }\end{array}$ & $\begin{array}{l}\text { Domain } \\
\text { Included }\end{array}$ & $\begin{array}{c}\text { F-Ratio } \\
\& \\
\text { Signif. } \\
\text { Levels }\end{array}$ & $\begin{array}{c}\text { Domain } \\
\text { Not } \\
\text { Included }\end{array}$ & $\begin{array}{l}\text { Domain } \\
\text { Included }\end{array}$ & $\begin{array}{c}\text { F-Ratio } \\
\& \\
\text { Signif. } \\
\text { Levels }\end{array}$ & $\begin{array}{c}\text { Domain } \\
\text { Not } \\
\text { Included }\end{array}$ & $\begin{array}{l}\text { Domain } \\
\text { Included }\end{array}$ \\
\hline Multivariate: & $\begin{array}{l}2.42461 \\
p<.083\end{array}$ & & & $\begin{array}{l}.91227 \\
\mathrm{p}<.443\end{array}$ & & & $\begin{array}{l}.99300 \\
p<.409\end{array}$ & & & $\begin{array}{l}2.32635 \\
p<.132\end{array}$ & & \\
\hline $\begin{array}{l}\text { Profit Margin } \\
\text { 1988: }\end{array}$ & $\begin{array}{l}2.06452 \\
p<.159\end{array}$ & $\begin{array}{r}.479^{a} \\
(.103)\end{array}$ & $\begin{array}{l}.372 \\
(.189)\end{array}$ & $\begin{array}{l}1.20388 \\
p<.278\end{array}$ & $\begin{array}{r}.398 \\
(.174)\end{array}$ & $\begin{array}{c}.468 \\
(.171)\end{array}$ & $\begin{array}{l}.15814 \\
p<.694\end{array}$ & \begin{tabular}{|l}
.409 \\
$(.135)$
\end{tabular} & $\begin{array}{r}.378 \\
(.189) \\
\end{array}$ & $\begin{array}{l}1.81241 \\
p<.198\end{array}$ & $\begin{array}{r}.682 \\
(.000) \\
\end{array}$ & $\begin{array}{r}.379 \\
(.218) \\
\end{array}$ \\
\hline $\begin{array}{l}\text { Profit Margin } \\
\text { 1989: }\end{array}$ & $\begin{array}{l}5.09715 \\
p<.030\end{array}$ & $\begin{array}{l}.531 \\
(.163)\end{array}$ & $\begin{array}{c}.363 \\
(.180)\end{array}$ & $\begin{array}{l}1.24144 \\
p<.271\end{array}$ & $\begin{array}{r}.381 \\
(.189) \\
\end{array}$ & $\begin{array}{l}.450 \\
(.164)\end{array}$ & $\begin{array}{r}1.17779 \\
p<.286\end{array}$ & $\begin{array}{c}.475 \\
(.189) \\
\end{array}$ & $\begin{array}{c}.385 \\
(.198) \\
\end{array}$ & $\begin{array}{l}1.09731 \\
p<.311 \\
\end{array}$ & $\begin{array}{r}.610 \\
(.000) \\
\end{array}$ & $\begin{array}{c}.374 \\
(.218) \\
\end{array}$ \\
\hline $\begin{array}{l}\text { Profit Margin } \\
\text { 1990: }\end{array}$ & $\begin{array}{l}1.94788 \\
\mathrm{p}<.171\end{array}$ & $\begin{array}{c}.470 \\
(.100)\end{array}$ & $\begin{array}{c}.362 \\
(.198)\end{array}$ & $\begin{array}{l}1.90211 \\
p<.175\end{array}$ & $\begin{array}{l}.364 \\
(.205)\end{array}$ & $\begin{array}{l}.455 \\
(.171)\end{array}$ & $\begin{array}{r}1.29766 \\
p<.263\end{array}$ & $\begin{array}{c}.474 \\
(.193)\end{array}$ & $\begin{array}{l}.378 \\
(.200)\end{array}$ & $\begin{array}{l}.82968 \\
p<.377\end{array}$ & $\begin{array}{l}.575 \\
(.000)\end{array}$ & $\begin{array}{l}.370 \\
(.218)\end{array}$ \\
\hline $\mathrm{n}$ & & 7 & 31 & & 9 & 38 & & 7 & 27 & & 1 & 16 \\
\hline
\end{tabular}

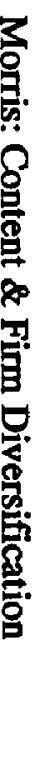

- Mean for the performance variable. Standard Deviations given in parenthesis. 
Table 7

Summary of Importance of Survival, Growth \& Profitability Mission Element

Multivariate and Univariate Analysis of Variance

Means and Standard Deviations

By Level of Diversification

\begin{tabular}{|c|c|c|c|c|c|c|c|c|c|c|c|c|}
\hline & \multicolumn{3}{|c|}{$\begin{array}{c}\text { Single } \\
\text { Product Firms }\end{array}$} & \multicolumn{3}{|c|}{$\begin{array}{l}\text { Dominant } \\
\text { Product Firms }\end{array}$} & \multicolumn{3}{|c|}{$\begin{array}{c}\text { Related } \\
\text { Diversified Firms }\end{array}$} & \multicolumn{3}{|c|}{$\begin{array}{c}\text { Unrelated } \\
\text { Diversified Firms }\end{array}$} \\
\hline $\begin{array}{l}\text { Performance } \\
\text { Variables }\end{array}$ & $\begin{array}{c}\text { F-Ratio } \\
\& \\
\text { Signif. } \\
\text { Levels }\end{array}$ & $\begin{array}{c}\text { Survival } \\
\text { Not } \\
\text { Included }\end{array}$ & $\begin{array}{l}\text { Survival } \\
\text { Included }\end{array}$ & $\begin{array}{l}\text { F-Ratio } \\
\& \\
\text { Signif. } \\
\text { Levels }\end{array}$ & $\begin{array}{c}\text { Survival } \\
\text { Not } \\
\text { Included }\end{array}$ & $\begin{array}{l}\text { Survival } \\
\text { Included }\end{array}$ & $\begin{array}{c}\text { F-Ratio } \\
\& \\
\text { Signif. } \\
\text { Levels }\end{array}$ & $\begin{array}{c}\text { Survival } \\
\text { Not } \\
\text { Included }\end{array}$ & $\begin{array}{l}\text { Survival } \\
\text { Included }\end{array}$ & $\begin{array}{l}\text { F-Ratio } \\
\& \\
\text { Signif. } \\
\text { Levels }\end{array}$ & $\begin{array}{l}\text { Survival } \\
\text { Not } \\
\text { Included }\end{array}$ & $\begin{array}{l}\text { Survival } \\
\text { Included }\end{array}$ \\
\hline $\begin{array}{l}\text { Multivariate } \\
\text { Profit Margin: }\end{array}$ & $\begin{array}{l}2.11242 \\
p<.117\end{array}$ & & & $\begin{array}{l}1.29282 \\
p<.289\end{array}$ & & & $\begin{array}{l}2.21869 \\
p<.106\end{array}$ & & & $\begin{array}{l}.05513 \\
p<.982\end{array}$ & & \\
\hline $\begin{array}{l}\text { Profit Margin } \\
\text { 1988: }\end{array}$ & $\begin{array}{l}.21006 \\
p<.649\end{array}$ & $\begin{array}{l}.368^{\mathrm{t}} \\
(.202) \\
\end{array}$ & $\begin{array}{c}.399 \\
(.176)\end{array}$ & $\begin{array}{l}.30281 \\
\mathrm{p}<.585\end{array}$ & $\begin{array}{l}.485 \\
(.220)\end{array}$ & $\begin{array}{r}.448 \\
(.164)\end{array}$ & $\begin{array}{r}.03431 \\
p<.854 \\
\end{array}$ & $\begin{array}{l}.375 \\
(.163) \\
\end{array}$ & $\begin{array}{l}388 \\
(.186) \\
\end{array}$ & $\begin{array}{l}.40143 \\
p<.536\end{array}$ & $\begin{array}{l}.445 \\
(.221) \\
\end{array}$ & $\begin{array}{l}371 \\
(.231) \\
\end{array}$ \\
\hline $\begin{array}{l}\text { Profit Margin } \\
\text { 1989: }\end{array}$ & $\begin{array}{l}.26631 \\
p<.609\end{array}$ & $\begin{array}{l}.422 \\
(.246)\end{array}$ & $\begin{array}{l}.385 \\
(.170)\end{array}$ & $\begin{array}{l}.01410 \\
p<.960\end{array}$ & $\begin{array}{l}.443 \\
(.182)\end{array}$ & $\begin{array}{l}.436 \\
(.169)\end{array}$ & $\begin{array}{r}.80800 \\
p<.375\end{array}$ & $\begin{array}{l}.454 \\
(.213)\end{array}$ & $\begin{array}{l}.385 \\
(.192)\end{array}$ & $\begin{array}{l}.16839 \\
p<.687\end{array}$ & $\begin{array}{l}.418 \\
(.201)\end{array}$ & $\begin{array}{l}.371 \\
(.236)\end{array}$ \\
\hline $\begin{array}{l}\text { Profit Margin } \\
\text { 1990: }\end{array}$ & $\begin{array}{l}.10298 \\
p<.750\end{array}$ & $\begin{array}{c}.364 \\
(.211)\end{array}$ & $\begin{array}{r}.387 \\
(.184)\end{array}$ & $\begin{array}{l}.06151 \\
p<.805\end{array}$ & $\begin{array}{l}.423 \\
(.176)\end{array}$ & $\begin{array}{c}.441 \\
(.182)\end{array}$ & $\begin{array}{l}.84349 \\
p<.365 \\
\end{array}$ & $\begin{array}{l}.451 \\
(.211) \\
\end{array}$ & $\begin{array}{r}.379 \\
(.197) \\
\end{array}$ & $\begin{array}{l}.10661 \\
p<.749\end{array}$ & $\begin{array}{l}.406 \\
(.196) \\
\end{array}$ & $\begin{array}{l}.369 \\
(.236) \\
\end{array}$ \\
\hline$\pi$ & & 9 & 29 & & 8 & 39 & & 9 & 25 & & 6 & 11 \\
\hline $\begin{array}{l}\text { Multivariate } \\
\text { ROA: }\end{array}$ & $\begin{array}{l}3.00218 \\
p<.043\end{array}$ & & & $\begin{array}{l}2.41633 \\
p<.079\end{array}$ & & & $\begin{array}{l}.17944 \\
p<.910 \\
\end{array}$ & & & $\begin{array}{l}2.13474 \\
p<.142 \\
\end{array}$ & & \\
\hline ROA 1988: & $\begin{array}{l}4.36692 \\
p<.044\end{array}$ & $\begin{array}{l}-.063 \\
(.247) \\
\end{array}$ & $\begin{array}{r}.043 \\
(.078) \\
\end{array}$ & $\begin{array}{l}7.42820 \\
p<.009\end{array}$ & $\begin{array}{c}.147 \\
(.226) \\
\end{array}$ & $\begin{array}{l}.032 \\
(.071) \\
\end{array}$ & $\begin{array}{l}.25584 \\
p<.616 \\
\end{array}$ & $\begin{array}{l}.061 \\
(.057) \\
\end{array}$ & $\begin{array}{r}.051 \\
(.052) \\
\end{array}$ & $\begin{array}{r}.00285 \\
\mathrm{p}<.958\end{array}$ & $\begin{array}{c}.045 \\
(.049) \\
\end{array}$ & \begin{tabular}{|c|}
.043 \\
$(.063)$ \\
\end{tabular} \\
\hline ROA 1989: & $\begin{array}{r}1.59028 \\
p<.215 \\
\end{array}$ & $\begin{array}{c}.009 \\
.129) \\
\end{array}$ & $\begin{array}{l}.052 \\
(.076) \\
\end{array}$ & $\begin{array}{l}4.84651 \\
p<.033\end{array}$ & $\begin{array}{l}.145 \\
(.271) \\
\end{array}$ & $\begin{array}{r}.045 \\
(.054) \\
\end{array}$ & $\begin{array}{l}.24980 \\
\mathrm{p}<.620\end{array}$ & $\begin{array}{c}.062 \\
(.059) \\
\end{array}$ & $\begin{array}{c}.051 \\
(.057) \\
\end{array}$ & $\begin{array}{l}.00088 \\
p<.977\end{array}$ & $\begin{array}{c}.045 \\
(.049) \\
\end{array}$ & $\begin{array}{c}.046 \\
(.056) \\
\end{array}$ \\
\hline ROA 1990: & $\begin{array}{l}2.33962 \\
\mathrm{p}<.135 \\
\end{array}$ & $\begin{array}{c}.019 \\
(.075) \\
\end{array}$ & $\begin{array}{c}.059 \\
(.066) \\
\end{array}$ & $\begin{array}{l}.13305 \\
p<.717 \\
\end{array}$ & $\begin{array}{r}.059 \\
(.082) \\
\end{array}$ & $\begin{array}{c}.051 \\
(.053) \\
\end{array}$ & $\begin{array}{l}.00420 \\
\mathrm{p}<.949\end{array}$ & $\begin{array}{l}.049 \\
(.076) \\
\end{array}$ & $\begin{array}{l}.047 \\
(.053) \\
\end{array}$ & $\begin{array}{l}.89048 \\
p<.359 \\
\end{array}$ & $\begin{array}{c}.020 \\
(.028) \\
\end{array}$ & $\begin{array}{r}.056 \\
(.052) \\
\end{array}$ \\
\hline$\overline{\mathbf{n}}$ & & 9 & 30 & & 8 & 40 & & 9 & 27 & & 6 & 11 \\
\hline
\end{tabular}

"Mean for the performance variable. Standard deviation given in parenthesis. 
as measured by ROA. The mean return on assets for related diversified firms including the customer element in their annual report was significantly higher than for firms who did not discuss customers. This mirrors the relationship that was found for single-product firms in 1988. Once again it is difficult to provide an explanation for the importance of the customer element to firm performance in 1988 as opposed to other years.

For unrelated diversified firms significant F-ratios are observed for the multivariate profit margin and ROA measures as well as for each annual profit margin or ROA. In each of the three years included in this analysis, the mean profit margin (or ROA) for unrelated diversified firms including the customer element in their mission is significantly different from unrelated diversified firms that did not discuss customers in their mission. Unrelated diversified firms that did not explicitly identify their customers in their missions had a higher average profit margin and ROA than unrelated diversified firms that included a discussion of customers. These findings have an intuitive appeal due to the unrelatedness of the businesses of the firms in this segment of the sample. Customers of a firm's unrelated divisions may be as unrelated as the divisions themselves, thus describing who the firm's customers are may not be effective in providing a unifying vision and strategic focus. Dwelling on the firm's customers may distract the unrelated diversified firm from more important strategic issues. Additional research incorporating a larger sample of unrelated diversified firms will be needed to further elaborate the relationship between firm performance and inclusion of the customer element in the mission.

For the geographic domain mission element (Table 6), no significant multivariate or univariate difference in financial performance was observed for firms following a dominant-product, related diversified or unrelated diversified strategy. Discussion of the firm's geographic markets was unrelated to firm performance for firms following anything but a single-product diversification strategy. Significant multivariate and univariate results were obtained for single-product firms. In 1989, single-product firms that included explicit references to the firm's markets in their mission experienced lower profit margins (on average) than firms following the single-product strategy that had omitted an elaboration of geographic markets. A focus on the firm's geographic markets may have come at the expense of more strategically important mission elements in identifying the firm's strategic direction. Specification of the firm's primary markets in the mission may reflect recent market expansions which may result in negative pressures on the firm's profit margin, thus providing a possible explanation for the lower average profit margins for single-product firms including the geographic domain component in their missions. This effect may be more pronounced in single product firms than for any of the other three categories of firm diversification. Because the content analysis procedure only measured whether the mission included or excluded the firm's target markets in the mission and not whether the market was appropriate given competitive conditions, another possible reason for the relative poor performance of single-product firms may be due to markets that are too restrictive or narrowly defined. 
Although the omnibus F-test for the survival, growth and profitability element (Table 7) indicated the relationship of this element with financial performance was contingent on the level of diversification, no significant multivariate or univariate results were obtained in the secondary MANOVAs when profit margin was considered. Only the multivariate F-ratio for firms following a related diversification strategy was marginally significant $(p<.106)$. No further explanation or interpretation of the initial significant F-ratio is possible given the results of the secondary analysis. When ROA is considered, significant multivariate and univariate F-ratios were observed for single-product and dominant product firms. Single-product firms that included language regarding their concern for survival, growth and profitability earned a higher rate of return on assets in 1988 than single-product firms that did not include this element. The opposite was observed for dominant product firms. In 1988 and 1989, dominant product firms that did not include the survival, growth and profitability element in their annual reports earned a higher rate of return on assets than firms including this element. The results for dominant product firms may be explained in part by the prevailing assumption that economic goals guide the strategic direction of almost every viable business firm and therefore need not be explicitly stated (Pearce, 1982). Firms that were performing well may not have felt it necessary to address economic issues in their annual reports. On the other hand, firms that were performing poorly may have devoted more of their texts to provide a rationale for their performance or to set out goals for future improvement. The opposite relationships observed in single-product and dominant product firms may be partially due to the small cell sizes in the categories for firms that did not include this element in their annual reports. Further research will be necessary to improve our understanding of this relationship.

Table 8 shows the results of the multivariate and univariate analyses for the self-image mission element. Significant multivariate and univariate results were found for single-product and dominant product firms. The inclusion or exclusion of the firm's self-image in the missions of related and unrelated diversified firms did not influence financial performance as shown by the lack of significant univariate or multivariate F-ratios for firms following diversification strategies. In 1989, single-product firms that omitted the self-image element from their mission yielded higher profit margins (on average) than single-product firms that included the self-image element. Since the self-image component addresses the firm's concept of its strengths and weaknesses, this finding appears to be contrary to expectations. Because annual reports are publicly available, inclusion of a firm's competitive strengths may prove advantageous to competitors formulating preemptive or retaliatory competitive strategies. Public disclosure of competitive strengths may be particularly harmful to firms following a single-product strategy. These findings should not be interpreted to suggest that single-product firms should not undergo strategic diagnosis to determine their competitive strengths, but to suggest that public disclosure of the results of such a diagnosis may have damaging effects on firm financial performance.

For dominant product firms, significant multivariate and univariate F-ratios reveal an opposite relationship between firm performance and disclosure of firm self-image. For all three years (1988-1990), dominant product firms that included a discussion of 
Table 8

Summary of Importance of Self-Image Mission Element Multivariate and Univariate Analysis of Variance

Means and Standard Deviations

By Level of Diversification

\begin{tabular}{|c|c|c|c|c|c|c|c|c|c|c|c|c|}
\hline & \multicolumn{3}{|c|}{$\begin{array}{c}\text { Single } \\
\text { Product Firms }\end{array}$} & \multicolumn{3}{|c|}{$\begin{array}{c}\text { Dominant } \\
\text { Product Firms }\end{array}$} & \multicolumn{3}{|c|}{$\begin{array}{c}\text { Related } \\
\text { Diversified Firms }\end{array}$} & \multicolumn{3}{|c|}{$\begin{array}{c}\text { Unrelated } \\
\text { Diversified Firms }\end{array}$} \\
\hline $\begin{array}{l}\text { Performance } \\
\text { Variables }\end{array}$ & $\begin{array}{l}\text { F-Ratio } \\
\& \\
\text { Signif. } \\
\text { Levels } \\
\end{array}$ & $\begin{array}{c}\text { Self- } \\
\text { Image } \\
\text { Not } \\
\text { Included }\end{array}$ & \begin{tabular}{l}
\multicolumn{1}{c}{ Self- } \\
Image \\
Included \\
\end{tabular} & \begin{tabular}{|c|} 
F-Ratio \\
$\&$ \\
Signif. \\
Levels \\
\end{tabular} & $\begin{array}{c}\text { Self- } \\
\text { Image } \\
\text { Not } \\
\text { Included }\end{array}$ & $\begin{array}{c}\text { Self- } \\
\text { Image } \\
\text { Included }\end{array}$ & $\begin{array}{c}\text { F-Ratio } \\
\& \\
\text { Signif. } \\
\text { Levels } \\
\end{array}$ & \begin{tabular}{|c|} 
Self- \\
Image \\
Not \\
Included \\
\end{tabular} & $\begin{array}{l}\text { Self- } \\
\text { Image } \\
\text { Included }\end{array}$ & $\begin{array}{c}\text { F-Ratio } \\
\& \\
\text { Signif. } \\
\text { Levels } \\
\end{array}$ & $\begin{array}{c}\text { Self- } \\
\text { Image } \\
\text { Not } \\
\text { Included }\end{array}$ & $\begin{array}{l}\text { Self- } \\
\text { Image } \\
\text { Included }\end{array}$ \\
\hline Multivariate & $\begin{array}{r}4.12897 \\
p<.013\end{array}$ & & & $\begin{array}{l}3.07093 \\
p<.038\end{array}$ & & & $\begin{array}{r}.63898 \\
p<.596\end{array}$ & & & \begin{tabular}{|l|l}
.48405 \\
p<.699
\end{tabular} & & \\
\hline $\begin{array}{l}\text { Profit Margin } \\
\text { 1988: }\end{array}$ & $\begin{array}{l}1.14531 \\
p<.292\end{array}$ & $\begin{array}{c}.498^{\mathrm{a}} \\
(.075)\end{array}$ & $\begin{array}{l}.383 \\
(.184)\end{array}$ & $\begin{array}{l}8.90339 \\
\mathrm{p}<.005 \\
\end{array}$ & $\begin{array}{r}.254 \\
(.074) \\
\end{array}$ & $\begin{array}{l}.479 \\
(.165) \\
\end{array}$ & $\begin{array}{l}1.41912 \\
p<.242\end{array}$ & $\begin{array}{r}.501 \\
(.217)\end{array}$ & $\begin{array}{r}.373 \\
(.174)\end{array}$ & $\begin{array}{l}1.43056 \\
p<.250\end{array}$ & $\begin{array}{r}.653 \\
(.000) \\
\end{array}$ & \begin{tabular}{|r|}
.381 \\
$(.221)$ \\
\end{tabular} \\
\hline $\begin{array}{l}\text { Profit Margin } \\
\text { 1989: }\end{array}$ & $\begin{array}{r}5.04078 \\
p<.031 \\
\end{array}$ & $\begin{array}{l}.615 \\
(.194) \\
\end{array}$ & $\begin{array}{l}.375 \\
(.177) \\
\end{array}$ & $\begin{array}{l}9.41640 \\
p<.004 \\
\end{array}$ & $\begin{array}{l}.235 \\
(.094) \\
\end{array}$ & $\begin{array}{c}.461 \\
(.160) \\
\end{array}$ & $\begin{array}{r}.79089 \\
p<.380\end{array}$ & $\begin{array}{r}.500 \\
(.206) \\
\end{array}$ & $\begin{array}{l}.394 \\
(.197)\end{array}$ & $\begin{array}{l}1.21400 \\
p<.288\end{array}$ & $\begin{array}{r}.620 \\
(.000)\end{array}$ & \begin{tabular}{|l|}
.373 \\
$(.218)$ \\
\end{tabular} \\
\hline $\begin{array}{l}\text { Profit Margin } \\
\text { 1990: }\end{array}$ & $\begin{array}{r}.94620 \\
\mathrm{p}<.337 \\
\end{array}$ & $\begin{array}{l}.483 \\
(.071) \\
\end{array}$ & \begin{tabular}{|l}
.373 \\
$(.193)$ \\
\end{tabular} & $\begin{array}{l}9.32067 \\
\mathrm{p}<.004\end{array}$ & $\begin{array}{l}.225 \\
(.088) \\
\end{array}$ & $\begin{array}{c}.463 \\
(.171) \\
\end{array}$ & $\begin{array}{r}.91203 \\
\mathrm{p}<.347\end{array}$ & $\begin{array}{r}.503 \\
(.218) \\
\end{array}$ & $\begin{array}{l}.388 \\
(.199)\end{array}$ & $\begin{array}{l}1.20523 \\
p<.290\end{array}$ & $\begin{array}{c}.612 \\
(.000)\end{array}$ & \begin{tabular}{|l|}
.368 \\
$(.216)$ \\
\end{tabular} \\
\hline In & & 3 & 35 & & 5 & 42 & & 3 & 31 & & 1 & 16 \\
\hline
\end{tabular}

${ }^{2}$ Mean for the performance variable. Standard deviation given in parenthesis. 
the self-image component in their missions had higher (on average) profit margins than dominant product firms that did not include the self-image element. Although this finding is more in tune with expectations, the conflict with the findings for single-product firms is indeed puzzling. Dominant product firms that had explicitly discussed their competitive strengths in their missions earned higher profit margins than firms that did not. Why is such a dramatic difference observed between dominant product and single-product firms? Before becoming alarmed by these inconsistencies, additional research will be necessary to affirm that these differences truly exist.

A significant interaction term was observed for the public image element when ROA was used as the performance measure. As Table 9 shows, the significant multivariate and univariate results for dominant product firms are the source of the significant interaction.

Although the difference is only marginally significant, firms following a dominant product strategy earned a higher rate of return on assets in 1988 when public image was not included in their annual reports than did firms that included this element. While firms are often concerned about their public image in the absence of expressed public concern, a negative public image often prompts firms to articulate their beneficial aspects in public communications such as annual reports (Pearce, 1982). By this reasoning, firms that included public image in their mission statements may have been responding to negative public opinion which may have also negatively influenced their financial performance. A positive public image would be particularly important to dominant and single-product firms due to their concentration on a narrow business scope. No significant multivariate or univariate differences were observed in the ROAs of single-product, related diversified or unrelated diversified firms with regard to the inclusion of the public image element.

Since the interaction term for the technology mission element was insignificant, the significant main effect can be interpreted directly. Thus, the results show that financial performance is influenced by the inclusion or exclusion of the technology component regardless of the level of diversification. Profit margin means and standard deviations for firms that included the technology element in their missions versus those that did not include a discussion of technology are provided as Table 10.

Contrasts comparing the profit margin means resulted in significant differences ( $p$ $<.05$ ) between the univariate means for all levels of the diversification factor. At all levels of diversification, firms that did not include the technology element in their missions enjoyed higher profit margins than firms that included a description of their core technologies in their missions.

Because company spokespersons attributed the omission of the technology component to difficulties in "succinctly describing the many technologies on which their multiple products depended," Pearce and David concluded that the technology component was "far more relevant to smaller, more narrowly focused businesses" (Pearce \& David, 1987; p. 111). This rationale was not supported by the MANOVA results. 
Table 9

\section{Summary of Importance of Public Image Mission Element \\ Multivariate and Univariate Analysis of Variance, \\ Means and Standard Deviations}

By Level of Diversification

\begin{tabular}{|c|c|c|c|c|c|c|c|c|c|c|c|c|}
\hline & \multicolumn{3}{|c|}{$\begin{array}{c}\text { Single } \\
\text { Product Firms }\end{array}$} & \multicolumn{3}{|c|}{$\begin{array}{c}\text { Dominant } \\
\text { Product Firms }\end{array}$} & \multicolumn{3}{|c|}{$\begin{array}{c}\text { Related } \\
\text { Diversified Firms }\end{array}$} & \multicolumn{3}{|c|}{$\begin{array}{c}\text { Unrelated } \\
\text { Diversified Firms }\end{array}$} \\
\hline $\begin{array}{l}\text { Performance } \\
\text { Variables }\end{array}$ & $\begin{array}{l}\text { F-Ratio } \\
\& \\
\text { Signif. } \\
\text { Levels }\end{array}$ & $\begin{array}{c}\text { Public } \\
\text { Image } \\
\text { Not } \\
\text { Included }\end{array}$ & $\begin{array}{l}\text { Public } \\
\text { Image } \\
\text { Included }\end{array}$ & $\begin{array}{l}\text { F-Ratio } \\
\& \\
\text { Signif. } \\
\text { Levels }\end{array}$ & $\begin{array}{c}\text { Public } \\
\text { Image } \\
\text { Not } \\
\text { Included }\end{array}$ & $\begin{array}{l}\text { Public } \\
\text { Image } \\
\text { Included }\end{array}$ & $\begin{array}{c}\text { F-Ratio } \\
\& \\
\text { Signif. } \\
\text { Levels }\end{array}$ & \begin{tabular}{|c|} 
Public \\
Image \\
Not \\
Included
\end{tabular} & $\begin{array}{l}\text { Public } \\
\text { Image } \\
\text { Included }\end{array}$ & $\begin{array}{c}\text { F-Ratio } \\
\& \\
\text { Signif. } \\
\text { Levels }\end{array}$ & $\begin{array}{c}\text { Public } \\
\text { Image } \\
\text { Not } \\
\text { Included }\end{array}$ & $\begin{array}{l}\text { Public } \\
\text { Image } \\
\text { Included }\end{array}$ \\
\hline $\begin{array}{l}\text { Multivariate } \\
\text { ROA: }\end{array}$ & $\begin{array}{l}1.18996 \\
p<.328\end{array}$ & & & $\begin{array}{l}2.63989 \\
p<.061\end{array}$ & & & $\begin{array}{r}1.43468 \\
p<.251\end{array}$ & & & $\begin{array}{r}.17849 \\
p<.909\end{array}$ & & \\
\hline ROA 1988: & $\begin{array}{l}1.62690 \\
p<.210\end{array}$ & $\begin{array}{l}-.017^{\mathrm{a}} \\
(.216) \\
\end{array}$ & $\begin{array}{c}.041 \\
(.050) \\
\end{array}$ & $\begin{array}{l}3.77858 \\
p<.058\end{array}$ & $\begin{array}{l}.101 \\
(.176) \\
\end{array}$ & $\begin{array}{l}.031 \\
(.176) \\
\end{array}$ & $\begin{array}{l}.94201 \\
p<.339\end{array}$ & $\begin{array}{l}.045 \\
(.053) \\
\end{array}$ & $\begin{array}{l}.062 \\
(.053) \\
\end{array}$ & $\begin{array}{l}.49674 \\
p<.617\end{array}$ & $\begin{array}{c}.028 \\
(.052) \\
\end{array}$ & $\begin{array}{l}.050 \\
(.065) \\
\end{array}$ \\
\hline ROA 1989: & $\begin{array}{r}.25615 \\
p<.616\end{array}$ & $\begin{array}{c}.033 \\
(.127)\end{array}$ & $\begin{array}{c}.048 \\
(.061) \\
\end{array}$ & $\begin{array}{l}1.54626 \\
\mathrm{p}<.220\end{array}$ & $\begin{array}{c}.096 \\
(.209) \\
\end{array}$ & $\begin{array}{c}.048 \\
(.057) \\
\end{array}$ & $\begin{array}{l}1.74799 \\
p<.195\end{array}$ & $\begin{array}{c}.042 \\
(.061)\end{array}$ & $\begin{array}{c}.067 \\
(.051)\end{array}$ & $\begin{array}{l}.25988 \\
p<.617\end{array}$ & $\begin{array}{c}.037 \\
(.059) \\
\end{array}$ & $\begin{array}{c}.051 \\
(.054) \\
\end{array}$ \\
\hline ROA 1990: & $\begin{array}{l}.02273 \\
\mathrm{p}<.881\end{array}$ & $\begin{array}{c}.047 \\
(.094)\end{array}$ & $\begin{array}{c}.051 \\
(.051)\end{array}$ & $\begin{array}{l}2.36571 \\
p<.131\end{array}$ & $\begin{array}{l}.032 \\
(.051)\end{array}$ & $\begin{array}{l}.060 \\
(.059) \\
\end{array}$ & $\begin{array}{l}.01000 \\
p<.921 \\
\end{array}$ & $\begin{array}{l}.047 \\
(.063) \\
\end{array}$ & \begin{tabular}{|c|}
.063 \\
$(.055)$ \\
\end{tabular} & \begin{tabular}{|l|}
.37047 \\
$p<.551$ \\
\end{tabular} & $\begin{array}{r}.042 \\
(.060) \\
\end{array}$ & $\begin{array}{l}.058 \\
(.048) \\
\end{array}$ \\
\hline$\pi$ & & 6 & 32 & & 12 & 35 & & 11 & 23 & & 4 & 13 \\
\hline
\end{tabular}

${ }^{2}$ Mean for the performance variable. Standard deviation given in parenthesis. 
Table 10

\section{Profit Margin Means and Standard Deviations \\ By Inclusion or Exclusion of Technology \\ And By Level of Diversification}

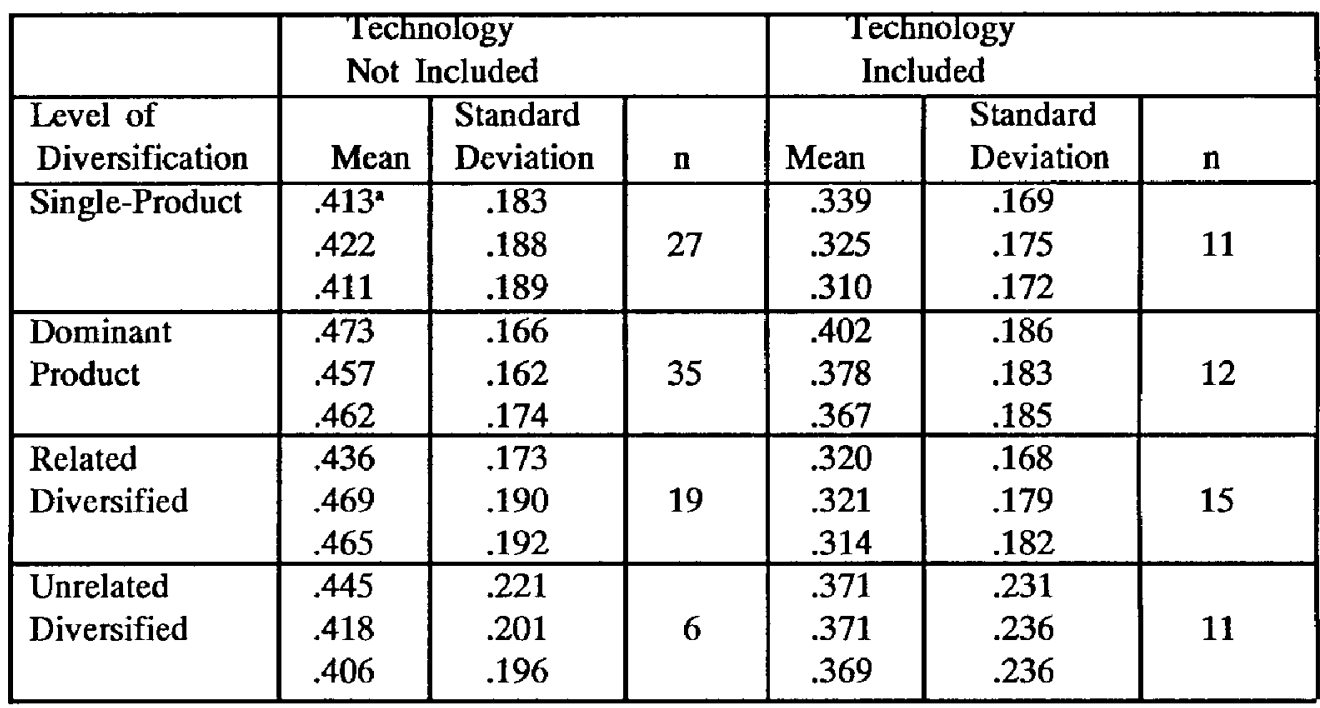

Profit margin means for 1988, 1989 and 1990. Standard deviations for 1988, 1989 and 1990. All means are significantly different at the $p<.05$ level.

Rapidly changing technologies may provide an explanation for the lower average profit margins of firms that included the technology component in their missions. By not tying the firm's future strategies to a specific technology that may become obsolete, firms that did not emphasize the technology component may be more flexible in adapting to future changes. It would be interesting to study whether this finding is more pronounced in the latter 1980's and early 1990's than at other times in history when technology was not changing as rapidly.

In summary, this exploratory study of 141 Fortune 500 firms yields a different picture of the relationship of firm mission content to firm financial performance than shown in the Pearce and David (1987) study. The results show that the firm's level of diversification does influence the magnitude and direction of the relationship between financial performance and mission content for some mission elements. Significant mission element by level of diversification interactions were observed for the customer, geographic domain, self-image, public image and survival mission elements thus providing support for a new model of the "ideal" mission statement which stresses the importance of strategic context in determining which of the mission elements are essential for inclusion. Differences in the findings of this study and those of earlier studies may be due to the use of a multiple measure of financial performance in the current study as opposed to the single measure used in Pearce and David (1987). As 
explained earlier, the differences could also be due to differences in the environmental pressures encountered by firms at different time periods of data collection.

Some of the cautions expressed by Pearce and David (1987) bear repeating here. Financial performance is affected by many variables besides those examined in these studies of mission statement components. Their findings and the present findings are not meant to suggest that improvements in financial performance could be obtained by simply including or excluding certain elements from a firm's mission statement. As Pearce and David (1987) pointed out, firms can have comprehensive mission statements and still experience poor sales and profits due to some other reasons. The findings of the current study and those of Pearce and David are important in demonstrating the relationships between mission statement content and financial performance and the need for additional empirical research to further establish the strategic contexts in which certain mission elements are more desirable.

\section{Summary}

The results of the current study demonstrate a need for a hierarchical model of mission statements much like the strategy hierarchy. The strategic needs of single-product, dominant product, related diversified and unrelated diversified firms are significantly different enough to warrant mission statement models which take these differences into account. Intuitively, the model of corporate mission statements proposed by Hill and Jones (1992) and described in the literature review section of this paper has considerable appeal. Their model parallels the defined role of corporate level strategy nicely, utilizing a portfolio approach to the firm's mission at the corporate level and supplementing it with more detailed business level mission statements. Diversified firms might follow such a model in creating their own mission statements.

The intended practical contribution of the present research was to suggest to practitioners that the most effective mission statement for their firm was one which was tailored to their unique strategic situation. There is no magic check-list of items that must be contained in the mission statement to ensure firm profitability. If the mission statement is to be effective in providing a strategic direction for the firm, it must address the unique aspects of a firm's strategic context rather than follow a "generic" mission statement format. Pearce and David (1987) recognized this need in their original article, but unfortunately, their work has often been misinterpreted as providing a blueprint for creating the "ideal" mission statement.

The exploratory results presented in this paper should provide a foundation for future research which seeks to determine the importance of certain mission components in a variety of different strategic contexts. Although the current research demonstrates the need to consider the diversification strategies of firms in mission statement research, other contextual variables such as industry characteristics, ${ }^{6}$ and a host of external environmental variables such as economic conditions, international operations, intensity of competitive rivalry, and others may prove important in developing better models of mission statement content. 


\section{Endnotes}

1 The views of Campbell (1989) and Klemm et al. (1991) may reflect a cultural difference with respect to the descriptive content, purpose, and audience of mission statements as both studies utilized samples of firms operating in the U.K. Mission statements have not been as widely utilized in the U.K. as in the U.S. although this may be changing (Klemm et al.,1991)

2 Under FASB-14, publicly held companies are required to report disaggregated financial information for segments considered significant to the enterprise as a whole. Significance is determined by three $10 \%$ tests, the first of which states, that a segment is considered significant and therefore reportable if its revenue is at least $10 \%$ of the firm's revenues from all segments. The two other $10 \%$ tests examine percentage of operating profits and losses accounted for by each segment and percentage of identifiable assets attributed to each segment. The requirements of FASB-14, therefore, make it possible to use financial reports in the classification of the level of diversification in publicly held companies. See Delancy, Adler, Epstein \& Foran (1994) for a further explanation of segment reporting requirements.

${ }^{3}$ Disclosure of this data is a further requirement of FASB-14.

${ }^{4}$ For a more complete description of the development, operation and validation of the computerized content analysis program for evaluating mission statements, see Morris (1994).

${ }^{5}$ The performance variables were not averaged in the analysis, but were entered as a group of three dependent variables in each MANOVA analysis. There was no mixing of performance variables. Profit margin measures wete only analyzed with other profit margin measures and not with ROA or ROE. The MANOVAs thus examine overall group differences that may not have been detected if each dependent variable had been used separately (Hair et al., 1992).

6 A recent study by Subramanian \& Kumar (1993) demonstrated that hospital mission statements were more likely to include a different subset of mission elements components than firms in the Pearce and David (1987) sample of firms in manufacturing industries.

\section{References}

Abell, D.F. 1980. Defining the Business: The Starting Point of Strategic Planning. Englewood Cliffs, NJ: Prentice-Hall.

Below, P.J., Morrisey, G.L. \& Acomb, B.L. 1987. The Executive Guide to Strategic Planning. San Francisco: Jossey-Bass, Inc.

Boseman, F.G. \& Phatak, A.V. 1989. Strategic Management. New York: John Wiley \& Sons. 
Bradley, P.H. \& Baird, J.E., Jr. 1977. "Management and Communication Style: A Correlation Analysis." Central States Speech Journal, 28, 194-203.

Bray, J.H. \& Maxwell, S.E. 1990. Multivariate Analysis of Variance. Newbury Park, CA: Sage Publications.

Campbell, A. 1989. "Does Your Organisation Need a Mission?” Leadership and Organization Development Journal, 16(3), 3-9.

Chatterjee, S. \& Blocher, J.D. 1992. “Measurement of Firm Diversification: Is It Robust?” Academy of Management Journal, 35(4), 874-888.

Cochran, D.S. \& David, F.R. 1986. "Communication Effectiveness of Organizational Mission Statements." Journal of Applied Communication Research, 14(2), 108-118.

Cooley, W.W. \& Lohnes, P.R. 1971. Multivariate Data Analysis. New York: John Wiley \& Sons.

D’Aveni, R.A. \& MacMillan, I.C. 1990. "Crisis and Content of Managerial Communications: AStudy of the Focus of Attention of Top Managers In Surviving and Failing Firms." Administrative Science Quarterly, 35, 634-657.

David, F.R. 1993. Strategic Management (Fourth edition). New York: Macmillan Publishing.

- - . 1989. "How Companies Define Their Mission.” Long Range Planning, 22(1), 90-97.

David, F.R. \& Cochran, D.S. 1987. "A Study of Mission Statements Among Large U.S. Manufactur ers." Journal of Business Strategies, 4(2), 59-67.

Delaney, P.R., Adler, J.R., Epstein, B.J. \& Foran, M.F. 1994. GAAP: Interpretation and Application of Generally Accepted Accounting Principles (1994 Edition). New York: John Wiley \& Sons.

Digman, L.A. 1990. Strategic Management: Concepts, Decisions, Cases. Homewood, IL: Richard D. Irwin.

Drucker, P.F. 1973. Management: Tasks, Responsibilities and Practices. New York: Harper \& Rowe.

Gephart, R.P. \& Wolfe, R.A. 1989. “Qualitative Data Analysis: Three Microcomputer-Supported Approaches." In Academy of Management Best Paper Proceedings Ed. F. Hoy ,(pp. 382-386). Washington, D.C.

Hair, J.F., Jr., Anderson, R.E., Tatham, R.L. \& Black, W.C. 1992. Multivariate Data Analysis. New York: MacMillan.

Hill, C.W.L. \& Jones, G.R. 1992. Strategic Management: An Integrated Approach. Boston, MA: Houghton Mifflin.

Ireland, R.D. \& Hitt, M.A. 1992. “Mission Statements: Importance, Challenge and Recommendations For Development.” Business Horizons, May-June, 34-42. 
Keppel, G. 1982. Design and Analysis: A Researcher's Handbook. Englewood Cliffs, NJ: Prentice-Hall.

Klemm, M., Sanderson, S. \& Luffman, G. 1993. "Mission Statements: Selling Corporate Values to Employees." Long Range Planning, 24(3), 73-78.

Kotler, P. 1984. Marketing Management. Englewood Cliffs, NJ: Prentice-Hall.

McGinnis, V.J. 1981. "The Mission Statement: A Key Step In Strategic Planning," Business, November-December, 39-43.

Montgomery, C.A. 1982. "The Measurement of Firm Diversification: Some New Empirical Evidence." Academy of Management Joumal, 25(2), 299-307.

Morris, R.J. (1994). "Computerized Content Analysis in Management Research: A Demonstration of Advantages and Limitations." Journal of Management. 20 (4), 903-931

Palia, K.A., Hitt, M.A., Ireland, R.D. \& Godiwalla, Y.H. 1982. Grand Corporate Strategy and Critical Functions: Interactive Effects of Organizational Dimensions. New York: Praeger Publica tions.

Pearce, J.A., II, 1982. “The Company Mission as a Strategic Goal." Sloan Management Review, 23(3), 15-24.

- - . 1991. Strategic Management: Formulation, Implementation and Control. Homewood, IL: Richard D. Irwin.

Pearce, J.A., II, \& David, F. 1987. "Corporate Mission Statements: The Bottom Line." Academy of Management Executive, 1(2), 109-115.

Porter, M.E. 1987. "From Competitive Advantage to Corporate Strategy." Harvard Business Review, May-June, 43-59.

Ramanujam, V. \& Varadarajan, P. 1989. "Research On Corporate Diversification: A Synthesis". Strategic Management Journal, 10, 523-551.

Rumelt, R.P. 1974. Strategy, Structure, and Economic Performance. Boston: Division of Research, Graduate School of Business Administration, Harvard University.

Smith, G.D., Arnold, D.R. \& Bizzell, B.G. 1991. Business Strategy and Policy. Boston, MS: Houghton Mifflin.

Steiner, G. 1979. Strategic Planning: What Every Manager Must Know. New York: The Free Press.

Subramanian, R., \& Kumar, K. 1993. "Mission Statements of Hospitals: An Empirical Analysis of Their Contents and Their Relationship to Organizational Factors." Journal of Business Strategies, 10(1), 63-78. 
Thompson, A.A., Jr., \& Strickland, A.J., III, 1992. Strategic Management: Concepts_and Cases. Homewood, IL: Richard D. Irwin.

Want, J.H. 1986. Corporate Mission. Management Review, 75(8), 46-50.

Watzlawick, P., Beavin, J.H., \& Jackson, D.D. 1967. Pragmatics of Human Communication: A Study of Interactional Patterns, Pathologies and Paradoxes. New York: W.W. Norton.

Weber, R.P. 1990. Basic Content Analysis. Newbury Park, CA: Sage Publications.

Wright, P., Pringle, C.D. \& Kroll, M.J. 1992. Strategic Management: Text and Cases. Boston, MS: Allyn and Bacon.

Wrigley, L. 1970. Divisional Autonomy and Diversification. Doctoral dissertation. Harvard University. 